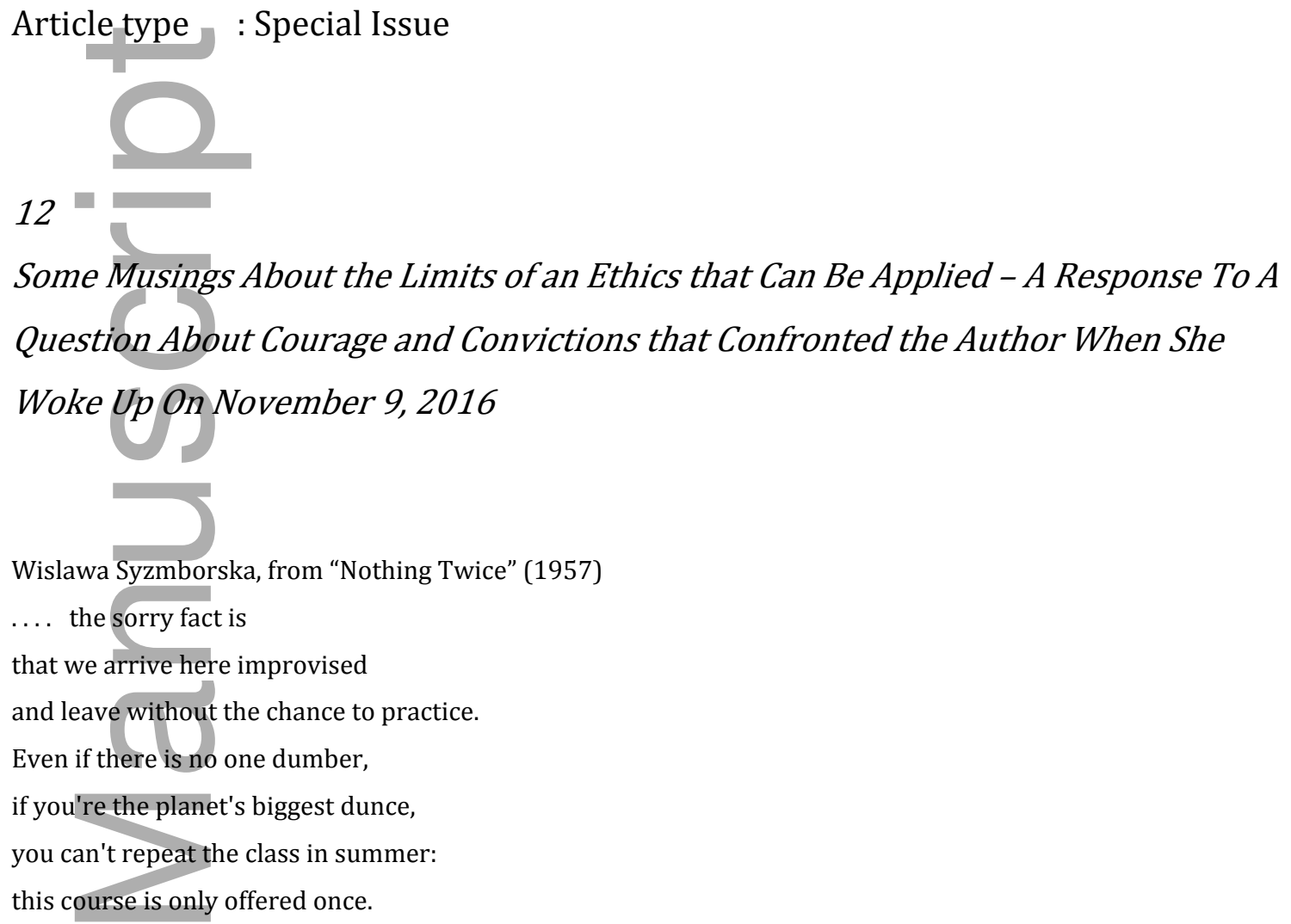

This is the author manuscript accepted for publication and has undergone full peer review but has not been through the copyediting, typesetting, pagination and proofreading process, which may lead to differences between this version and the Version of Record. Please cite this article as doi: 10.1111/JAPP.12408 
CASE 1: Imagine a detailed description of a group of people -- they could be peasants, they could be urban dwellers -- who have almost no legally protected power over the conditions of their lives, and no civil and political liberties, in particular. (The description I have in mind could be in a novel -- think Tolstoy -- or a work of history.)

We are offered no grounds for criticizing these people. To the contrary, the summary suggests that there is something admirable about the way they made the best of a bad situation. Their days were filled with hard labor. They were at the mercy of those who had power over every aspect of their lives. Yet they did not complain. They raised families and vegetables; they had meaningful friendships. When they weren't working or sleeping, they spent their time enjoying the company of their family and friends. All the while, they accommodated their political circumstances as they accommodated the weather. They put up with the constraints on their choices, and with the arbitrary exercise of power to which they and their neighbors were subjected. They did their best not to provoke the wrath of those who had tight control over their lives, refraining from protesting when this wrath was directed at others. Under the circumstances, this coping strategy was, as we say, the better part of wisdom.

CASE 2: Imagine a detailed description of those who did not oppose Hitler -- the "Good Germans," but also, accommodators in other countries where the final solution was enforced. Focus on those among these people who had good reason to believe that they would be ostracized or lose their jobs, or worse, if they were in any way to challenge the actions or policies of those in power, or even lend a hand to those who were already targets of the regime's displeasure, or refuse to give various signs of support to this regime. ${ }^{2}$

These people, too, were at the mercy of those who had power over every aspect of their lives. And they, too, did not complain. They raised families and vegetables; they had meaningful friendships. When they were not working or sleeping, they

This article is protected by copyright. All rights reserved 
spent their time enjoying the company of their family and friends. Yet they are not widely admired -- certainly not for their willingness to accommodate their political circumstances without complaint. To the contrary, they (or, if you like, some significant portion of those who fit the description) are widely agreed to have been cowardly accomplices to evil. Many of them were later tormented by guilt and shame. In the place of the idioms that come naturally when describing the others, we fault these accommodators for keeping their heads down, and not being willing to stick out their necks.

This prompts the question: What is the morally relevant difference between these two cases? And what does the answer to this question suggest about most of the people going about their business as inoffensively as possible today -- in Russia, North Korea, Egypt, Saudia Arabia, Pakistan, China, Hungary, Singapore, Venezuela, Turkey,....

My interest in this question is, in part, theoretical: I am interested in what grappling with this question can teach us about moral ideals and human virtue, and the limits of applied ethics But it is also -- and even more importantly -- personal: I would like to know when my accommodation to an oppressive regime would have the moral significance of the accommodation exemplified in the first case, and when it would have the moral significance of the accommodation exemplified in the second case. When would I be admirably (or at least permissibly) making the best of a bad situation if I were to go on with my life while the people in political power deprived my fellow citizens and me of the basic right to express our opinions, or to assemble for political purposes? And when would I be contemptibly betraying ideals that I myself claim to hold dear?

I want to leave to one side conditions under which my failure to protest injustice would reflect my desire to live as well as I can, or a thoughtless tendency to conform. I want to know when going morally astray would be an act of cowardice. More particularly still, I want to know when (i) becoming an accomplice to 
inhumane and unjust laws, policies, and actions would reflect a failure to appreciate that this is what I am, in fact, doing, and when (ii) this failure would itself reflect the influence, not of greed or hatred, or malice or laziness or despair, but fear -- a reasonable fear for my safety and security. I realize, of course, that there are bound to be many borderline cases, and many cases whose location relative to the line is extremely difficult for anyone to discern -- even, sometimes, long after the event. ${ }^{3}$ But this does not give me any reason to be less concerned. To the contrary, I seek guidance precisely because the moral territory is so murky.

As the title of this paper indicates, my quest in the pages that follow takes the form of "some musings." I use the term deliberately: the reader hoping for a systematic treatise will be disappointed. In the pages that follow, one question gives rise to another in a way that is intended to capture my train of thought. These questions include: What lessons can we draw from those who have opposed injustice (whether overtly or covertly) at (the risk of) great cost to themselves? What does the answer to this question suggest about the relation between courage and selflove? What are the conditions necessary for having an end one believes to be far more important than preserving one's life and liberty? What qualifies someone as having such an end, given that no one can be disqualified by the mere fact that there are many circumstances under which she would refrain from promoting this end in order to promote her most fundamental interests? Are we justified in refraining from an act of resistance if it is very likely to have no beneficial effect? Though I express many opinions on these and other matters, and though I do my best to explain what tempts me to hold them, my "conclusions" are tentative; each suggestion is offered as a provocation for further inquiry. If there is a main thesis, it is not very surprising: we must settle for something far less reassuring than the sort of recipe for moral discernment I was hoping to find. ${ }^{4}$ The secondary, somewhat more tentative, thesis is that the capacity to distinguish reasonable accommodations to injustice from cowardly accommodations may require - or at any rate, be strengthened by -- an attitude toward oneself that is in tension with the commitment to justice itself.

This article is protected by copyright. All rights reserved 
Case I and Case II have served their purpose if they have exposed the challenge we face in trying to apply the Socratic insight that doing the wrong thing is worse than suffering even terrible losses. ${ }^{5}$ As my use of the word "insight" indicates, I am firmly on Socrates's side. This does not mean, however, that whether an action (or an omission) will lead one to suffer terrible losses is irrelevant to whether it would be wrong. We have good reason to protect ourselves, and may even have some obligation to do so. This is no less true when, all things considered, we are obligated to suffer great losses. In such cases, the value of protecting ourselves merely ceases to override the considerations on the other side.

The two cases point to how important it is to be able to weigh the demands of self against the demands associated with our moral ideals; and they point to how difficult it is to find anything one can reliably apply in order to make the proper assessment. Though this observation concerns wrongdoing of all sorts, the actions and inactions that concern me here involve failures to stand up for basic human rights, and for the human beings whose rights are being violated. Would I be a coward if I were to refrain from stating my views publicly because I did not want my name to be added to a list of government enemies? What if I were to lie or to hedge when directly asked? Or to refuse to sign a petition? Or to keep my distance from friends and neighbors who are trying to work together to improve the situation? Or to refuse to appear as a witness in their defense? When would I be wrong to salute the flag or give some other sign of support for the regime in power? When would I be wrong to accept a job that was affiliated with the regime? ${ }^{6}$

Before considering how one might try to answer these questions, I want to elaborate briefly on the basic assumption that underlies my inquiry: the assumption that we sometimes do wrong by keeping our heads down and pulling our necks in -- even if such behavior is necessary in order to avoid the very gravest harms to ourselves. This assumption is, I want to stress, perfectly compatible with the assumption that 
harming others in order to achieve some end is generally morally worse than making no effort to prevent others from doing harm -- and worse, too, than declaring one's support for those doing harm, or even working for institutions that help them maintain their power. Without rejecting these moral distinctions, I believe that it is possible to support evil by doing nothing to oppose it. I assume further that we have positive duties, not only to help others in need, but also to support their fair treatment. I assume -- to put some flesh on the bones of Case II -that Pope John XXIII was correct to indict Pope Pius the XII and others for the "practice of prudence" that took the form of a failure to speak out against the massacres of Jews in the East. I endorse Hannah Arendt's claim that "if I obey the laws of the land, I actually support its constitution, as becomes glaringly obvious in the case of revolutionists and rebels who disobey because they have withdrawn this tacit consent."7 I endorse Mary McCarthy's claim that "if somebody points a gun at you and says, 'Kill your friend or I will kill you,' he is tempting you, that is all."8 And I assume that if "because otherwise I will die" is nevera sufficient reason for pulling the trigger, we cannot assume that it is always a sufficient reason for making no effort to tackle the assailant who is willing to perform the deed herself. I assume that though it is often wrong to do anything to oppose the wrongdoing of one's neighbors and colleagues, and though it is often at least permissible to do nothing to oppose their wrongdoing, there are cases in which one is obligated to intervene. I assume, for example, that I am morally obligated to make some effort to stop others from abusing their children.

And what if Ihave alreadymade "some effort"? This question calls attention to the respect in which the obligation to support basic human rights is like any imperfect duty: we do not violate this obligation whenever we are brushing our teeth or making breakfast, or even whenever we decline an invitation to a political rally in support of those whose rights have been violated. That having been said, I also assume that just as there are occasions on which turning one's back on someone in need is wrong, no matter how many others one has helped in the past, so too, one's past efforts to support the cause of justice (and one's willingness to make significant 
efforts in the future when this will not put one at such great risk) do not always provide one with an adequate justification for refusing to do what one must do now in order to avoid supporting the policies and actions of an unjust regime.

Unfortunately, none of these convictions provides me with answers to the questions raised three paragraphs earlier. This is surely tied to the many variables that appear to be relevant to properly balancing the demands of self against the demands of justice. Accommodation comes in degrees. So does injustice. One can support an unjust regime by refusing to help one of its victims in desperate need, or by refusing to help an opposition candidate. An unjust regime can direct its abuse of power exclusively at those who challenge its right to do so. Or it can target even those who do their best to accommodate. And the targeting can be selective (based on some characteristic that has nothing to do with political affiliation) or random. Some unjust regimes are a vast improvement over those that have immediately preceded them. Others deprive people of rights which these people had been given good reason to take for granted.

These differences -- and others -- are surely relevant to what distinguishes justified from unjustified accommodations to injustice. To take just the last difference: those of us who are lucky enough to have enjoyed freedom of speech and association may have a special obligation to defend these rights when they begin to be undermined. It may be that in failing to defend them, we would be shirking our responsibilities as self-governing citizens -- responsibilities that citizens of other countries do not have.

How are we to "weigh" all the relevant considerations against each other? ${ }^{9}$ From what I can tell, the principles that spell out the conditions of right action are simply too general, and too indeterminate, to do the job. This not only means that such principles are of no help when we confront the sort of choice situation that especially concerns me here. As Arendt notes, their generality and indeterminacy is also a meta-temptation of sorts: it tempts us to give in to the temptation to give too 
much weight to the demands of self, by tempting us to apply these principles in a self-serving way. This, Arendt argues, is why so few "respectable" Germans did anything to oppose the Nazis: "yielding easily to temptation, they most convincingly demonstrated through their application of traditional concepts and yardsticks ..., how inadequate these had become, how little ... they had been framed or intended to be applied to conditions as they actually arose."10

I leave the search for principles to others. Given my pessimism about the prospects of this enterprise, I think it is more promising to pursue a different strategy. I want to ask, instead: which dispositions should I cultivate in order to be in the best possible position to appreciate the contours of the moral terrain when I confront the sort of choices that interest me here? It is important to stress that in raising this question, my ultimate objective remains the same: I want to understand what I am morally obligated to do under the stipulated circumstances. More importantly, I want to be capable of discerning what I am morally obligated to do should I find myself in these circumstances. My worry that, when push comes to shove, I might do the wrong thing, is -- fundamentally -- the worry that I might not have a sufficiently clear understanding of the distinction between right and wrong. This is the danger to which Arendt refers when she warns against "yielding to temptation." Her point is not that "respectable" people are vulnerable to doing the very thing they believe they have insufficient reason to do even as they are doing it. ${ }^{11} \mathrm{Her}$ point, rather, is that it is very tempting for us to believe that we have sufficient reason to do whatever we must do in order to save our own skin. Under the influence of fear, it is tempting for us to justify our refusal to accept significant losses by appealing to the pointlessness of sticking our necks out, and/or to other conflicting obligations we need to fulfill, and/or to other things we must do first, and/or to other good deeds we would be prevented from undertaking at some point in the future.

There are circumstances under which we need courage in order to do the right thing because we need courage in order to see things aright. These include circumstances 
in which protecting oneself against grave injury requires not lifting a finger to support the very conditions one claims to value far more highly than one's own life and liberty. If under these circumstances I am to have some hope of being able to discern the boundary between what duty requires and what is beyond its call, I need to consider what I must do in order to render myself less vulnerable to the desire to protect myself, and less vulnerable, in particular, to the distorting influence of fear. Having briefly explained why I think there are insurmountable impediments to what one might call "anti-cowardice training," I will then turn my attention to the possibility of cultivating a more fear-proof relation to myself. I will consider the claim this self-relation has to being a component of practical wisdom, as well as the threat it may pose to such wisdom. Throughout my inquiry, my aim will be to discover how I might acquire the courage to see which accommodations to injustice are compatible with my own moral ideals.

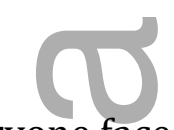

Everyone faces temptations. But if we are lucky -- as in this respect most of the people reading this essay surely are -- then the sort of actions that typically tempt us do not involve protecting ourselves from danger at the expense of others. They are, rather, actions at the expense of others that would enhance the conditions of our (already rather comfortable) lives. The vice associated with such temptations is greed, broadly conceived: the disposition to acquire more than one's fair share -more food, more attention, more power, more privilege. Learning how to be a decent human being is, to a large extent, a matter of learning how to resist such temptations, and ultimately, not even to be tempted. From a very early age, most of us (again, the lucky ones) get lots of practice in such self-denial. And in the usual course of things, this eventually leads to the emergence of a less demanding -- less greedy -- self. $^{12}$

We also have many opportunities to practice overcoming our fears. But though we thereby learn how to be less risk-averse, these are not typically lessons in selfdenial. If we are lucky enough to live under circumstances where there are no 
pervasive, credible threats to, as we sometimes put it, our person, then our lessons in becoming less cowardly are lessons in overcoming unfounded, exaggerated, fears (where their unfoundedness is often a matter of their being unjustifiably strong). Yes, some dogs bite. But most dogs don't. Yes, there will always be nasty people who say cruel things. But the danger they pose is really not all that great. Failure is inevitable. But it is not to be feared to the point where one refuses to try.

For those of us lucky enough to live among people who generally treat each other with concern and respect, lessons in how to be less cowardly are thus typically lessons in how to promote our own interests. These lessons are self-enhancing, not just in the sense that we improve ourselves whenever we acquire a virtue. In learning how not to be so afraid of failing, we enhance our ability to behave prudently; we develop the resources we need in order to get what we want.

This is all well and good. Yet it does nothing to advance our ability to appreciate how to interpret our fears when they urge us to accommodate injustice. Nor, I should add, does such training prepare us to deal with our fear for the safety of our loved ones in cases where accommodating injustice is the only way to keep them safe. We may, of course, have had some experience facing moral dilemmas. But whatever difficulties are involved in determining the relative priority of one's duties to all human beings and one's duties to the members of one's family, these are not the difficulties involved in combating cowardice. They are not the challenges we face when we need to know whether our desire to accommodate injustice is dictated by our apprehension of a competing duty, or whether it is -- disproportionately, if not exclusively -- the expression of our fear of great, irremediable, loss.

Even when fear is reasonable, or fitting, it tends to function like a vice in disposing us to give undue weight to ourselves. Nothing, it tells us, is more important than self-preservation. ${ }^{13}$ This is not the brute self-assertion of someone crying out in pain. Rather, it is a claim about how the reasons add up. The point of the preceding reflections is that few of us have had the opportunity to develop dispositions of self- 
denial on which we can rely in order to determine when to trust this claim and when not to. We have not had the sort of training that would prepare us to appreciate when we should resist the dear self's demand to protect it from the sort of significant losses that threaten our ability to live a minimally secure, and at least not terribly uncomfortable, life. We have had even less training in actually resisting this demand.

Of course, bad luck could strike in other forms that would present someone with the opportunity of developing the sort of capacity that interests me here. Someone could, for example, be frequently forced to interact with bullies, or with people who say hateful things about others, and who can exact a high price from anyone who objects. I hope, however, that suffering under such adverse circumstances is not a necessary condition for developing the capacity to distinguish justifiable accommodations to an unjust regime from unjustifiable accommodations. More importantly, in observing that we need this capacity in other circumstances too, we get no closer to understanding how to develop it.

To some extent the difficulty to which I am calling attention reflects a more general phenomenon. As David Wiggins notes, we cannot "measure in advance what exactly any kind of commitment lets [us] in for, either in and of itself or in relation to all [our] distinct commitments (whatever theymay prove to amount to)."14 It seems to me, however, that the novelty of the unfamiliar circumstances that concern me is especially worrisome in this respect. Not only do I lack adequate insight into what my commitments to a just social order, to human and civil rights and basic human decency commit me to do under circumstances in which I can expect to pay a high price for doing anything to support these ideals; it also seems that in my present moral condition, I have good reason to doubt that what I cannot "measure exactly in advance" will acquire a size and shape I can rely on when the moment of decision is upon me.

This article is protected by copyright. All rights reserved 
Someone has good reason to worry if she knows that she lacks the training she will need in order to pass an important test she may one day be required to take. If what will be tested is her ability to resist the temptation to offer her precious self more protection than it has any right to expect, then she will be worried about whether she can count on herself to do the right thing. Will her fear get the better of her? Will the moral ambiguities she is sure to confront when the stakes are high provide her with an excuse to put her reason to use in serving her fear? How will she act in the face of profound uncertainty? How will she know how to act?

We have here an instance of the fear of self which the existentialists call "anxiety," or "dread." These students of the contorted dynamics of self-consciousness would surely diagnose my desire to fortify myself against moral confusion as a symptom of this very dread. Are they right to insist that all such quests are necessarily hopeless? If, when we face the temptation to accommodate injustice, we cannot rely on any action-guiding principles, and if we cannot rely on any previous anticowardice training, might this not mean that whatever it is to be practically wise, only a fool would assume that there must be something she can do to be prepared to correctly assess the moral challenges that matter most?

There are certainly limits to what anyone can do to develop the sort of capacity for moral discernment I seek. This is one of Marlow's chief lessons in Joseph Conrad's Lord Jim. According to Marlow, to be truly wise is to realize that no work of ethics, and no moral training, contains anything we can "apply" when we are wondering whether, in going on with our lives as usual in the shadow of an oppressive regime, we will be crossing a moral line. "It is," Marlow declares, "from weakness unknown, but perhaps suspected, as in some parts of the world you suspect a deadly snake in every bush -- from weakness that may lie hidden, watched or unwatched, prayed against or manfully scorned, repressed or maybe ignored more than half a lifetime, not one of us is safe." 15 "I had," he later explains, "hoped for the impossible -- for the laying of what is the most obstinate ghost of man's creation, of the uneasy doubt uprising like a mist, secret and gnawing like a worm and more chilling than the 
certitude of death -- the doubt of the sovereign power enthroned in a fixed standard of conduct. It is the hardest thing to stumble against; it is the thing that breeds yelling panics and good little quiet villainies; it's the true shadow of calamity.... "16

\begin{abstract}
Marlow stresses the impossibility of securing oneself against doing something contemptible in response to fear. No amount of training can ensure against a moment of weakness. No fixed standard of conduct has a sovereign power on which we can rely in the moment of truth. The point is obvious as soon as we consider it. Yet as our relation to our mortality clearly indicates, something obvious and important need not be something we take very seriously. This, too, is Marlow's point: to take one's own moral vulnerability seriously is to prompt feelings of dread.
\end{abstract}

In discussing this fear, Marlow emphasizes our inability to fortify ourselves against morally contemptible motivations; Jim's failure to stay with the passengers on board the endangered ship was, most obviously, a failure of will. But our limitations are necessarily epistemic as well as motivational. Indeed, Jim would not have failed to do the right thing had he not failed to see his situation aright.

Even if, moreover, from our comfortable vantage point, it is obvious what Jim ought to have done (he ought not to have abandoned the ship, though there was very good evidence that it was about to go down, killing everyone on board), this hardly means that this would have been obvious to us if we had been on deck ourselves. In the hard cases, the details always matter. It is the details that determine the difference between (i) being "an infernal coward" for notmaking an effort to save one's own skin $^{17}$ and (ii) being brave enough not to try to save it. There is no complete list of such details, nor of the moral significance each detail might have. Thus Marlow reminds us: “it's easy enough to talk of Master Jim, after a good spread, two hundred feet above the sea-level, with a box of decent cigars handy, on a blessed evening of freshness and starlight that would make the best of us forget we are only on sufferance here and got to pick our way in cross lights, watching every precious 
minute and every irremediable step, trusting we shall manage yet to go out decently in the end -- but not so sure of it after all....."18

Robert Adams describes a disturbing occasion on which Dietrich Bonnhoeffer chided a friend for not giving the Hitler salute. "If," Adams muses, "Bonhoeffer had a unique opportunity, by pretending to be a Nazi, to assure the success of a conspiracy to overthrow the Nazi regime, then I think it would be irresponsible for him to refuse to give the Hitler salute, despite its moral distastefulness. On the other hand, if there was no realistic hope of successful resistance, conspiratorial or otherwise, to Nazism within Germany, then the symbolic protest of refusing to salute might have been the best available way of being against Nazism." "Probably," Adams continues, "Bonhoeffer's actual situation lay somewhere between those extremes, though closer than he could believe to the more pessimistic one. This illustrates a more general point .... What it is reasonable or good, or even makes sense, to do depends on our possibilities of action, and thus on our situation in the world. What that situation is ... is subject to great uncertainty." 19 "Unique opportunities" and "unrealistic hopes of resistance" do not come clearly marked. Nor does the moral significance of the fact that a given opportunity is very-good-though-hardly-unique, or that, for all one can tell, one's hopes might be unrealistic. This is another way of saying that even if, as Adam Gopnik notes in a recent article on the civil rights movement, "resilience and resistance are the same activity, seen at different moments in the struggle" -- even if, we can add, it is sometimes better to preserve oneself as a witness -- it is often far from clear which "moment" we are now in. ${ }^{20}$

Aware of one's own moral vulnerability, wondering what one should and will think and do when the time comes, one may try running through various scenarios in one's head --- or in a philosophy paper. But as Adams and Conrad remind us, we would be foolish to count on such exercises as something we can apply to some future life experience. Indeed, as Marlow notes, by imagining ourselves standing up bravely for what is right and good, we are as likely to encourage the demands of the confused, frightened self as we are to learn how to ignore them. Before his 
ignominious jump, Jim's thoughts were "full of valorous deeds: he loved these dreams and the success of his imaginary achievements. They were the best parts of life, its secret truth, its hidden reality. They had a gorgeous virility, the charm of vagueness, they passed before him with a heroic tread; they carried his soul away with them and made it drunk with the divine philter of an unbounded confidence in itself. There was nothing he could not face."21

This powerful warning could serve as a conclusion to my attempt to understand what distinguishes the two cases of accommodation with which I began, and a conclusion, too, to my attempt to discover a form of anti-cowardice training that would enable me to make the relevant distinctions when this is not merely an intellectual exercise. This conclusion should perhaps have been obvious from the outset: there is very little we can do in philosophy or in life to prepare ourselves to properly assess and respond to a situation in which we are tempted to accommodate an unjust regime that represents a credible threat to the most fundamental aspects of our lives; there are no principles or exercises we can apply in order to determine when we would be admirably making the best of things and when we would be cravenly going along. This means that those of us who face very little risk in working to strengthen our political and legal institutions have a very good reason to make the necessary efforts -- a reason that supplements the many reasons having nothing to do with whatever anxiety we may feel about the condition of our mortal souls. In short: if we do not want our moral decency to depend on the luck of our circumstances, then we had better do what we can to ensure that the circumstances we find ourselves in do not put us to the test. ${ }^{22}$

This having been said, I want to keep my attention focused on those unlucky circumstances -- the very sort of circumstances in which millions and millions of human beings are living right now. The present inquiry was occasioned by my painful realization of how little space there may be between my moral decency and the remarkably fortunate fact that I have not lived under such circumstances myself. 
(This realization was occasioned, in turn, by the sudden discovery that the legal structures of my country are far more vulnerable than I had assumed. It is worth stressing, however, that nothing I say here depends on any particular assumptions about the present condition of U.S. democracy and what it portends. $)^{23}$ Though I do not want to forget Marlow's warning against assuming that we can prepare ourselves to behave decently under whatever circumstances may arise, I want to press on with my musings about what sort of dispositions might make us less likely to go morally astray under circumstances in which we cannot protect our lives, liberty, and livelihood without refraining from standing up for even the most basic human rights, and for the human beings whose rights are being systematically violated. Having noted the limits of anti-cowardice training, I want to shift my focus away from such training and onto those who don't seem to need it. I want to consider what we might learn about moral virtue from considering the stories of those who have (in fiction and real life) refused to accommodate injustice, at great risk to themselves.

What is special about these moral exemplars? How do they manage to conclude that they should stand up for their rights, and the rights of others, even though they have very compelling reasons not to? There are probably as many answers to this question as there are moral exemplars. I want to focus, however, on the reasonable hypothesis that self-love plays a less significant role in their decisions. Inspired by the example of these admirable human beings, I want to explore what it would take to cultivate an attitude that comes as close as any attitude possibly could to being the opposite of self-love. Having explained why I believe that this attitude is an important element of wisdom, and why, in particular, I believe that it is an antidote to the corrupting effects of reasonable fear, I will then call attention to the threat it nonetheless appears to pose to our ability to sustain the very moral convictions whose implications it gives us the courage to discern. In thus suggesting that there may be something deeply precarious about moral virtue, I will not reach a conclusion any more conclusive than Marlow's. I hope, however, that in exploring the relations between courage and the capacity to reason, practical wisdom and the 
capacity to overcome self-love, I will prompt further reflections on what it would take for us to be less dependent on our circumstances for whether we "go out decently in the end."

We are not alone in the world. Solidarity with others helps us to find a courage we could not find on our own. This suggests a way forward that none of us can afford to ignore. Not only does effective resistance to systematic injustice usually require some sort of collective action; each of us is also less vulnerable to corruption when we form connections with others who share our ideals, making common cause with them, forging fellowships of various kinds. In the sort of political and legal situation I am imagining, however -- the sort of situation in which much of the world's people presently find themselves -- group organizing is itself a perilous activity; and it is quite possible (though hardly certain) that by refraining from such activity, one will never get into trouble with those in power. This is why I have chosen to focus on the contribution that other people can make to our moral virtue in their capacity as exemplars.

There are, we should not forget to marvel, many such models -- men and women of great courage who have refused to accommodate injustice. We should study these people, read their biographies and their testimonials. ${ }^{24}$ In so doing, we will not discover an ethical recipe we can straightforwardly apply to our own particular circumstances. But we will be reminded of what is possible -- what is possible for people like us.

As others have noted, one of the striking things about people who risk everything in order to do what they believe to be right is how often they do not take themselves to be acting "beyond the call of duty." Indeed, they often do not regard themselves as having any genuine alternative to acting as they do. Acting otherwise is, they often confess, simply unthinkable. 
In making this confession, these people are calling attention to a psychological fact, as well as a normative one. To be sure, their deeds are often the product of days and months -- sometimes years -- of soul-searching. But even when this is the case, it is not as though, at the moment of choice, they have finally figured out how to weigh up the pros and cons, and have, on this basis, concluded that they have no justification for pursuing any other alternative. Well aware of the fact that they cannot offer decisive arguments against those who make different choices, they may even remain unsure about whether they really have sufficiently compelling reason to act as they do. Yet this modesty about their moral stance does nothing to undermine its strength. David Shulman sums up this way of being in the world when he says "It is nothing to be right, and a true disaster to be righteous, but it is everything to do what you can." 25

This Delphic statement directs our attention to something distinctive about the way in which a morally admirable human being apprehends and responds to what can, must, and ought to be done. In so doing, it forces us to consider how what distinguishes the moral exemplars from the rest of us is related to their significance as exemplars. Trivially, where what one ought to do is what one cannot refrain from doing, nothing is easier than doing what one ought to do. But for precisely this reason, the moral exemplars might not seem to be of much help to us. The accommodations they find unthinkable are precisely the accommodations we cannot help regarding as very real options. So, it seems, they cannot be responding to our problem. So it seems they cannot serve as guides to how we should respond. On the other hand, we can hardly deny that what they believe they must do is something that we can do too. So, even though, for us, can and must come apart, the exemplars remind us that the impediments to action may not be as great as we think. ${ }^{26}$

I will return in a moment to the suggestion that doing what one can is "everything." First, I want to say a few words about other factors that make it easier for us to see what we ought to do, and easier to do it. As Shulman notes in discussing his 
commitment to resisting Israeli settlement activity, the motives that underlie a person's opposition to injustice are as complex and varied as the human beings themselves. In addition to the solidarity I mentioned a moment ago ("nothing is worse than the shame of letting [one's friends] down"), there is "anger" -- "the rage at having been lied to by our government for years and years, at having been made silently complicit in their crimes." ${ }^{27}$ Often, too, there is "the need to put oneself to the test." 28

In addition to these and other motives, however, all moral exemplars are sustained by "some inchoate, stubborn moral sense." 29 For those of us who make a living thinking about right and wrong, it is important to remind ourselves that this "sense" is not the output of reasoning. Its "stubbornness" is its status as a nonnegotiable touchstone. It imposes a condition on which movements in thought qualify as sound reasoning, and which episodes of equally impeccable inference drawing are just so many rationalizations, evasions, and delaying tactics. Someone with a "stubborn moral sense" is someone whose very reason is conditioned by an apprehension of what is important and good. Inchoate though this understanding may be, it fortifies her against doubt and fear, and the moral missteps to which these mutually reinforcing conditions give rise. This is what accounts for her conviction that it is unthinkable to accommodate the unjust and inhumane actions she risks her own well-being in order to oppose.

This conviction is stubborn, and yet -- to repeat -- it is tied to a profound modesty: "It is a true disaster to be righteous." Camus makes the same point with an oblique reference to the ancient doctrine that even those who actions are morally contemptible act under the guise of the good: "The most incorrigible vice is that of an ignorance that fancies it knows everything and therefore claims for itself the right to kill."

Camus's lesson, and Shulman's, is a deep one. And this brings us to what the moral exemplars can teach us about the relationship between ought and can. If, they 
suggest, one finds oneself in circumstances in which the line between justifiable and unjustifiable accommodations to injustice is difficult to discern, then even if one rightly believes oneself to be in grave danger, it is better to worry about what one can do in the service of the ideals one holds dear than to worry about how the reasons add up. If one focuses on the latter, one is likely to become confused, or even worse. As Dr. Rieux explains in The Plague, “A man can't cure and know at the same time. So let's cure as quickly as we can. That's the more urgent job." ${ }^{30}$

If what we can do under the circumstances at issue in this paper has priority over what we ought to do, this is because under these circumstances we cannot count on much help from our reason. (More carefully: we cannot count on our reason to settle the particular question at issue here.) If protecting ourselves requires accommodating injustice (without, however, requiring us to participate in any arrests, or to attack anyone's person, or in any other way to directly interfere with the lives of others), and if under these circumstances we cannot rely on any actionguiding principles or previous training to mark out the right course of action, then, as Arendt warns, there is little to prevent our reasoning from degenerating into selfserving rationalizing. When we lack the cognitive and motivational basis for resisting the temptation to employ our reason for the purpose of self-protection, we are ill advised to use this very same reason to assess the relative importance of our self-concern. ${ }^{31}$

On this point, too, Marlow is out ahead of us. Noting the intimate connection between cowardice and the disposition to weigh pros against cons in response to one's fears, he commends "that inborn ability to look temptations straight in the face -- a readiness unintellectual enough, goodness knows, but without pose -- a power of resistance, don't you see, ungracious, if you like, but priceless -- an unthinking and blessed stiffness before the outward and inward terrors, before the might of nature, and the seductive corruption of men -- backed by a faith invulnerable to the strength of facts, to the contagion of example, to the solicitation of ideas. Hang ideas! They are tramps, vagabonds, knocking at the back-door of your mind, each taking a little of 
your substance, each carrying away some crumb of that belief in a few simple notions you must cling to if you want to live decently and would like to die easy!"32

We must tread carefully here. In appealing to Shulman and Conrad and Camus as guides to the morally perplexed, I do not mean to suggest that we must abandon our reason in order to acquire the sort of moral decency that will enable us to do the right thing when this involves refusing to protect our precious selves. I mean that we must be disposed to give priority to what we can do when our reason does not appear to be of much help, and may even be likely to contribute to our confusion.

Relatedly, it is important to stress that “don't worry so much about how the reasons add up" is not advice for a psychopath or even for a newly minted moral agent. It applies to us, who have internalized the basic prima facie duties enumerated by W.D. Ross, and whose "moral sense" is thus very similar to that of the moral exemplars themselves. I am assuming that my readers and I are constrained by moral principles and that our moral training has disposed us to avoid going morally astray in any number of ways. The point is that, given that we are well-trained, principle-governed, conscientious moral agents, we are more likely to do the right thing in the sort of morally perplexing circumstances I am here discussing if we ask ourselves whether what appears to be an insurmountable impediment to an act of resistance really does prevent us from acting this way. If we focus on what we can do, we are more likely to do what we would do if we really had the priorities we attribute to ourselves.

But here an obvious question arises: under the relevant circumstances, aren't we likely to be every bit as uncertain about what we can do as we are about what we should do? The initial answer to this question is that because the former uncertainty concerns an empirical matter, we can resolve it more easily. When it comes to resolving normative questions, we must rely on our reason. So, if our reason does not yield a conclusive verdict about whether we ought to risk our necks for the sake of a given ideal, then we simply do not know what we should do. In 
contrast, there is a very simple extra-rational method for determining how far we can stick out our necks: we can simply give it a try.

Shulman notes, moreover, that there is an important sense in which we know what we can do even before we put ourselves to the test: we know we can try. Sometimes, he says, this is all we need to know. In particular, as long as we are confident that our efforts will not make things worse, there are occasions when it is irrelevant whether we will make a difference for the better. ${ }^{33}$ Doing what one can to support treating people humanely and justly may involve doing something "in a hopeless cause, with no witnesses." ${ }^{34}$

I will soon return to the (ir)relevance of making a difference. First, however, I want to consider whether, even if we leave this issue to one side, the preceding observations are really responsive to the predicament we face if, unlike the exemplars, we do not find keeping our heads down unthinkable. Isn't it an essential feature of this predicament that we cannot decide to (try to) be less accommodating without first discovering an adequate reason to be less accommodating? To know that we can try to stick out our necks a bit further is not to have adequate reason to do so. And given the likely costs involved in exposing ourselves in this way, could it really be reasonable for us to do so without adequate justification?

This line of thought rests on the reasonable assumption that our desire to protect ourselves from great loss is reasonable. Yet the moral exemplars to whom I have appealed are reasonable people too; they are not careless, imprudent risk-seekers. They appreciate as well as we do that there are more or less effective forms of opposition, that some risks are not worth taking, that it sometimes makes sense to bide one's time. Most of them also appreciate that some actions are "beyond the call of duty." What singles them out -- and what makes them less concerned about locating the line between the supererogatory and the obligatory -- is their refusal to put these facts to use in self-serving rationalizations. 
These last reflections remind us that accommodation comes in kinds and degrees. They also recall Adams's point that certain forms of accommodation can also be means of, or at least necessary conditions for the possibility of, resisting. In addition to these reminders, we need to keep in mind just how ordinary a brave person can be. In a remarkable essay on the relevance of stoic philosophy to the life of a soldier, Vice Admiral James Stockdale calls our attention to each of these facts. He shows us that one can form realistic plans of resistance even when one is a prisoner who is regularly subjected to torture. He shows us that even under these circumstances, "can" does not mean "can, if (and only if) you have more-than-ordinary human powers."

Only a very small number of POWs who were in the North Vietnamese jail with Stockdale for approximately seven and a half years failed to resist their jailors. They consistently resisted even though this meant "being bound with tourniquet-tight ropes, with care, by a professional, hands behind, jackknifed forward and down toward your ankles held secure in lugs attached to an iron bar, that, with the onrush of anxiety, knowing your upper body's circulation has been stopped and feeling the ever-growing induced pain and the ever-closing-in of claustrophobia, you can be made to blurt out answers, sometimes correct answers, to questions about anything they know you know." 35 No one can avoid blurting things out under these conditions. But, as Stockdale makes clear, one can pick ways of resisting when one is not "taking the ropes": "Don't bow in public; Stay off the air; Admit no crimes, Never kiss them goodbye." 36 And if (when you are not being tortured, and are thus able to choose what to do) you are offered the opportunity to "repent," turn it down.

In May of 1968 "the public address system [in the prison] blared out: "Those of you who repent, truly repent, will be able to go home before the war is over. Those few diehards who insist on inciting the other criminals to oppose the camp authority will be sent to a special dark place.'” As soon as this announcement was made, Stockdale used the prisoners' system of tapping codes on the cell walls (another mode of resistance) to "put out an order forbidding any American to accept early 
release." ${ }^{37} \mathrm{He}$ is keen to stress, however, that he was not "a lone man on a white horse. I didn't have to sell that one; it was accepted with obvious relief and spontaneous jubilation by the overwhelming majority." 38 As one soldier put it, "We can't refuse to do every degrading thing they demand of us, but [we can] pick out things we must all refuse to do unless and until they put us through the ropes again." "Give us the list," he told Stockdale (who was his commander): "what are we to take torture for?"39

Very few of us have someone to whom we can turn to receive this sort of order. We would not have it any other way. Precisely because no one is our commander, however, we need to be able to give ourselves lists of the relevant sort of imperatives -- to impose laws on ourselves, laws that are very specific -- as specific as: Don't bow in public. ${ }^{40}$ Such self-commands put flesh on the bones of one's moral ideals. They express these ideals; and they are an important way of ensuring that one does not betray these ideals even as one is making every effort to accommodate an inhumane and unjust system in many other ways.

Moral exemplars force us to see that drawing up such lists is itself something we can do. Given that these human beings -- who are at least as wise as we are -- have found ways to stand up for their ideals at great risk to themselves, we -- who are no more worth protecting than they are -- would seem to have good reason to believe that we can do likewise. ${ }^{41}$

Of course, brave people have dispositions that cowardly people lack: the dispositions constitutive of bravery! In particular, brave people are less prone than others to give in to the temptation to engage in self-serving rationalizations when they are faced with a serious threat. But this does not mean that those we admire for their courage have a special capacity for developing the relevant dispositions; to draw this conclusion would be to assume that to be virtuous just is to have a capacity for virtue that wrongdoers lack. Not only is this incompatible with holding anyone responsible for her misdeeds, but even if cowardice were an excuse, this 
would not imply that cowards are justified in making no effort to be more like the moral exemplars. An excuse is not a consideration in favor of doing something. To the contrary, it is one of the things that a justification is essentially not.

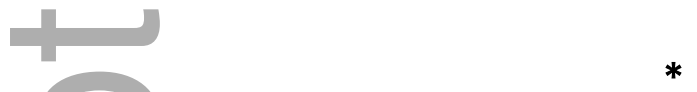

It is, of course, possible that developing the dispositions necessary for avoiding selfserving rationalizations is inseparable from coming to believe that one's moral obligations are more demanding than one was hoping to discover them to be. But if we are in danger of demanding too little of ourselves, then isn't this a risk worth taking? Indeed, isn't it a reasonable risk, even if we have obligations to ourselves, as well as to others? If we are obligated to preserve our own lives, this is an obligation to refrain from being careless and foolhardy -- not an obligation to protect ourselves at the expense of the ideals we (rightly) hold dear.

In short, though it is possible to err on the side of taking morally unnecessary risks to one's own well-being, I would rather make this sort of mistake when I am confident that I would not be doing anything wrong than refrain from sticking my neck out when I should. The moral exemplars suggest that I am less likely to err in the second way if I am more strongly disposed to do what I can. This prompts the question: is there anything I might do to strengthen this disposition?

In what remains of this paper, I will explore one response to this question I find especially intriguing. This response begins with a simple observation: if, as I have argued, moral exemplars focus more attention than most of us on what they can do, this seems to be because they focus less attention on themselves. More importantly, whatever their motivational structure may actually be, such people challenge us to consider the extent to which courage depends on a looser attachment to the self under threat. To be sure, people with the capacity to see what they ought to do under the sort of threatening circumstances that interest me here may be quite frightened about what will happen to them if they stand up to the forces of inhumanity and injustice; and they may be reasonably interested in discovering the 
safest way of standing up to these forces. Nonetheless, their fear and prudence do not manifest themselves in a paralyzing preoccupation with determining how to avoid paying the price of resistance. ${ }^{42}$ This, at any rate, is the hypothesis I wish to explore.

Insofar as the precious self figures less prominently in the deliberations of people with moral courage, these people satisfy a condition widely attributed to all varieties of virtue. True virtue, many philosophers point out, is not simply a matter of being disposed in most circumstances to give less weight to the reasons that favor stealing or lying or killing; it involves having no inclination to consider such reasons for wrongdoing in a wide range of circumstances. ${ }^{43}$ The examples offered in making this point are usually cases in which it is obvious to us, the readers, how a virtuous person would act. But moral exemplars who stick their necks out in defending basic human rights remind us that when it is not obvious to us whether we should take certain risks, this may well be because we are trying to determine the moral significance of self-protective actions whose efficacy we should not even be considering.

Not only, then, does privileging can over ought-- experiments in resistance over reasoning about whether it makes sense to resist -- enable morally conscientious human beings to shift their attention away from the reasons they have for keeping their heads down; being disposed to privilege can over ought also reflects the disposition to grant oneself a less privileged position among the things one considers in deciding what to do. I want to explore this admittedly rather vague hypothesis by exploring the hunch that the sort of courage we need in the sort of circumstances I am here discussing is inseparable from a profound kind of modesty. I am attracted to this idea, and I will try to present it in such a way as to reveal its attraction. My main aim, however, will not be to defend this conception of virtue, but to consider whether it is rational and/or possible to relate to oneself in this way, and whether, if so, this self-relation is a valuable (even essential) component of courage. I want to consider, too, whether, if someone is more likely to be brave 
when she relates to herself in this way, her courage -- her "blessed stiffness before the outward and inward terrors"-- is more likely to strengthen or to undermine her capacity for moral discernment. I will work my way up to these questions by first very briefly noting some other attitudes one might cultivate in order to overcome the morally corrupting influence of self-love.

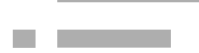

What would it take for me to be more strongly disposed to silence the demands of the precious self under circumstances when it seems to me that I would have to put myself at great risk in order to avoid accommodating injustice? If I were a (certain sort of) utilitarian, then this question would come down to the question of what it would take for me to care enough about others. If, as at least some utilitarians claim, a morally conscientious person were someone who gives no more weight to her own cares and concerns than she gives to anyone else's, then in order to establish the proper attitude toward my self-preservation, I would simply need to ask myself whether doing what is most likely to preserve my life would also preserve a greater number of other human lives -- or, perhaps, contribute more to the quality of such lives -- than anything else I might do. According to the utilitarians, if I fear that I will be disinclined to ask this question when my safety is at stake, then I had better get in the habit of asking it now.

Even if I were a utilitarian, however, I would not have much basis for thinking that my concern for the greatest good of the greatest number would suffice to enable me to discern which actions this concern calls for in the sort of circumstances that interest me here. More importantly for my purposes, I do not endorse a utilitarian conception of moral agency. My commitment to "doing the right thing" is not a commitment to giving equal weight to the interests of all beings with interests. Nor is it a commitment to identifying my interests with theirs. ${ }^{44}$ I cannot improve my ability to discern the moral distinctions that matter to me by determining which actions would maximize utility, or anything else. 
Hatred is another attitude that can dispose me to overcome the effects of fear. But even if there are occasions on which it is a fitting attitude, I will always strive to avoid it. I noted earlier that anger can also motivate us to be far less self-protective than we would otherwise be. But when it is mixed with fear, anger often moves us to find substitute, inappropriate, targets. Perhaps more importantly, I do not believe there is anything I could or should do now to become more strongly disposed to adopt this attitude under the circumstances in which it would move me to do the right thing.

It might seem that I could secure the sort of disposition I seek by cultivating a stronger love of others. But I do not seem to be able to love more than a very few individuals; and my love of "humankind" is even less tied to determinate imperatives than my commitment to doing "the right thing." The same limitations apply to the closely related attitudes of sympathy, empathy, and compassion.

In any case, my tendency to give too much consideration to my own precious self is not, most fundamentally, a problem concerning my relation to others. The problem is simply that I have too much love and sympathy for myself. If I am to solve this problem, I must acquire a greater indifference to my own fate; I must come to care about myself far less than I do now.

This suggestion evokes a comparison: "far less." It seems to me, however, that the economy of self-concern is such that unless caring far less is caring very little, it will have at most a small impact on the relative weight I give to my own well-being. Unless caring far less amounts to caring very little, my moral sense is unlikely to be sufficiently "stubborn" to prevent me from dwelling on how I might best protect myself when I know that I will put myself at far greater risk if I do what I suspect might well be the right thing to do. With this thought in mind, I want to consider the possibility of a more dramatic transformation in my attitude toward myself. I want to consider what it would be like if I were to cultivate a sort of indifference toward myself that I seem to have at least some reason to adopt, independent of whatever 
moral benefits will result. This indifference-as-profound-modesty might just as well be characterized as a modesty so profound as to approach indifference. It is an attitude that can be summed up with the simple acknowledgment that I am not really all that important.

This attitude does not imply that my life is not worth living, nor even that it is not quite wonderful to be alive. It is not to be confused with low self-esteem, or (if this is different) the belief that one is not worthy of respect. Nor does it imply that fear is never reasonable, nor that there is really no reason for me to look both ways before crossing the street. I suspect that those with more knowledge of Buddhism than I have could find more evocative ways of describing what I have in mind. The basic point is that my self-concern is a brute fact, not a well-founded appraisal -- and that a careful appraisal would raise serious questions about its warrant. On this way of looking at things, though I should certainly aim not to be foolhardy, if a car hits me before I make it to the other side, there is an important sense -- a sense important enough to be incorporated into my being-in-the-world, and thus important enough to have an impact on what I take into account when I decide what to do -- in which this unfortunate accident is really no big deal. If I need to make this point vivid, I can simply imagine how someone would appraise my life ten thousand years from now. My life and death matter very much to a very small group of people. But, as we say, "in the scheme of things," this is really not very much at all. ${ }^{45}$

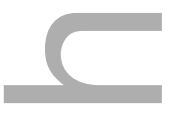

Surely, this insight is at least part of the Socratic lesson that philosophy is the art of learning how to die. ${ }^{46}$ The true philosopher has no interest in defending her ego; she delights in discovering where she has gone wrong. The true philosopher takes Truth and Justice and Beauty very, very seriously. But she takes a very different attitude toward herself. This is why she is not frightened that her devotion to Truth and Justice and Beauty will get her into trouble with the people in power. When they seek to put her to death on trumped up charges, she will stick up for herself. (She may even suggest that those in power reward her virtue with a lifetime's 
supply of delicious meals. ${ }^{47}$ ) But sticking up for herself will, for her, amount to nothing more nor less than sticking up for Truth, Justice, and Beauty. Having done what she can in their service, she will let the chips fall where they may. ${ }^{48}$

\begin{abstract}
According to Socrates, all philosophy is applied ethics. It is training in how to be good. Done right, philosophical inquiry involves no illusions of self-importance; and so, it involves no fear of self-annihilation. This is, in effect, Iris Murdoch's point when she commends the love of truth as an antidote to the psyche's "anxietyridden" need to "relentlessly look after itself." "Goodness," Murdoch says, "is connected with the acceptance of real death and real chance and real transience and only against the background of this acceptance, which is psychologically so difficult, can we understand the full extent of what virtue is like. The acceptance of death is an acceptance of our own nothingness which is an automatic spur to our concern with what is not ourselves." 49
\end{abstract}

If philosophy teaches us how to die, this is because, done right, it forces us to abandon the illusion of self-importance. One reason to do this is that, all else being equal, it is better to see things clearly. But, as the preceding reflections indicate, a further reason is that the more vividly we apprehend our own relative unimportance, the less vulnerable we will be to the vice of cowardice; we will be more inclined to focus our attention away from ourselves; and this will enable us to care more about what we can do than about whether we have good enough reason to do it. Of course, philosophy is not for everyone. And it is all too easy to engage in philosophical inquiry without absorbing the Socratic lesson. The point is simply that insofar as Socrates is a moral exemplar, this is because he exemplifies a way of relating to himself that we should all strive to emulate, regardless of whether we adopt his particular method for learning to relate to ourselves in this way.

Someone who is less firmly attached to herself than to basic human rights will find it especially difficult to "live with herself" while she wittingly accommodates injustice. The "self" at issue in the expression "I could not live with myself if I did that" is 
someone whose dispositions are incompatible with the moral ideals of the "I." For this "I" to say that she could not live with "herself" if she were to accommodate injustice in a certain way is for her to confess that, under these circumstances, there would be nothing left of this self with which she identifies. She is saying that she -the "I" -- would not be identical with the self she would be protecting. So, protecting this self would not be protecting herself. Protecting "herself" under these circumstances would be protecting a usurper. Better to die than to identify oneself with someone who is committed to betraying one's deepest ideals.

Arendt is among those who suggest that this feature of exemplars provides us with a heuristic of sorts: the most reliable criterion for determining when and how we are justified in accommodating evil, she suggests, is whether we can "live together with ourselves." ${ }^{50}$ It might seem that applying this criterion involves taking one's own integrity to be more important than anything else; and this would seem to be incompatible with the self-relation I have here been advocating. Though Arendt encourages this thought insofar as she contrasts (i) being concerned about whether one can live with oneself with (ii) being concerned about which actions are compatible with one's ideals, the thought -- like the contrast -- is confused. The point of calling the test of whether one can live with oneself a "heuristic" is simply that because one cannot endorse an ideal without believing that one ought not to betray it, the conviction that one would be betraying one's own ideals just is the conviction that one would be doing something wrong. Given that being "true to oneself" requires that one has assumptions about what one is justified in doing, the commitment to being "true to oneself" is no independent guide to doing the right thing; and so, it is not a guide that involves attributing supreme importance to oneself; and so, it is not incompatible with the commitment to learning how to die.

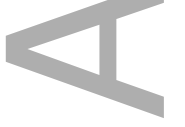

At the end of many hours of speaking to the journalist Gitta Sereny, Franz Stangl, Commandant of Treblinka, finally comes to see what he had not seen even long after the war: '“Yes,' he said finally, very quietly, 'in reality I share the guilt. ... Because 
my guilt ... my guilt ... only now in these talks ... now that I have talked about it all for the first time.... " He stopped... After more than a minute he started again, a half-hearted attempt, in a dull voice. 'My guilt,' he said, 'is that I am still here. That is my guilt.' 'Still here?' 'I should have died. That was my guilt.' 'Do you mean you should have died, or you should have had the courage to die? 'You can put it like that,' he said, vaguely, sounding tired now." ${ }^{51}$

This is the confession of someone who went along with one violation of basic rights after another until he was no longer just going along. Stangl is the anti-exemplar, if anyone is. And it is precisely as such that he is instructive. Ever anxious to protect himself and his family against catastrophic loss, he somehow lost sight of the fact that when it comes to being the commandant of an extermination camp, there are no pros to counter the cons.

Stangl is a vivid reminder of the fact that there are clear limits to what we are justified in doing to save our own skin, and that, nonetheless, our self-concern can so blur ourvision -- it can so corrupt our reason -- that we mistake the limits for the fuzzy boundaries. Not only can fear, and the associated demands of self, tempt us to justify our complicity with evil by tempting us to appeal -- more or less explicitly -to the obscure distinction between doing and allowing; it can also lead us to obscure the distinction between allowing others to act in ways incompatible with our ideals and betraying these ideals ourselves by what we allow others to do.

Stangl singles out one factor, in particular, that makes it especially difficult to accept that no further accommodation is justified. 'If I had sacrificed myself,' he said slowly, if I had made public what I felt, and had died.... it would have made no difference. Not an iota. It would all have gone on just the same, as if it and I had never happened."' This is his response to Sereny's suggestion that if he had "found the extraordinary courage" to "stand up for his principles," "it would have had an effect on the people who served under you." Though conceding the truth of his answer ("I believe that"), she nonetheless presses her point: "But even so, don't you 
think somewhere, underneath, it would have affected the atmosphere in the camp, would have given some others courage?'” Once again, Stangl demurs: "Not even that. It would have caused a tiny ripple, for a fraction of an instant -- that's all." ${ }^{52}$

Sereny suggests that, no matter how saturated with evil our circumstances may be, we can never be certain that "standing up for our principles" will have no beneficial results "somewhere, underneath." In making this point, she is more tentative than Arendt, who heaps scorn on those Germans who insisted that they would have stuck out their necks if only this would have done any good. There are, Arendt insists, no "holes of oblivion" in which brave human beings and their deeds will remain buried forever, benefitting no one in any way, not even as a source of inspiration..$^{53}$

But this is surely false. Not only will many acts of resistance come to naught, but even acts which have symbolic value only -- as expressions of what one "stands for" -- may cause no more than a tiny ripple, for a fraction of an instant -- that's all. Sereny is right that one can hardly ever be absolutely certain that this ripple will not turn into a wave. But surely, the probabilities are sometimes pretty clear. What matters in a case like Stangl's is not -- as Arendt and Sereny suggest -- whether any act of resistance is likely to have at least some small measure of utility. Rather, Stangl's mistake was that he was too concerned about himself to see that his life was not worth saving in the only way he believed he could save it. (In this respect, his decision is worth comparing with Conrad's Jim: Jim should not have jumped ship, even if he could have saved no lives by staying on board.) At other points in her work, Arendt concedes the point. The people, she tells us, who were willing to die rather than to support an evil regime acted as they did, not because "the world would then be changed for the better, but simply because only on this condition could they go on living with themselves at all." 5455

In thus insisting that efficacy is not a necessary condition of justified self-sacrifice, I am not retracting my earlier concession that tactical considerations are relevant to 
the (im)permissibility of any accommodating act or ommission. ${ }^{56}$ It is perhaps even more important to stress that I do not mean to be suggesting that the sort of indifference to self I am exploring here is easy to acquire. Though one's natural, primitive impulse to protect oneself is not a rational response to the value of what one is trying to protect, one can acknowledge as much while remaining disproportionately concerned about one's own well-being. Thus, nothing I have said in the last pages of this investigation challenges my initial conclusion that it is very difficult to develop the "the stubborn moral sense" that would enable me to recognize when I must be willing to suffer the sort of terrible losses an oppressive regime is willing to impose. Even if one sincerely believes that a cockroach crawling on one's face is no more threatening than a feather, one may be overwhelmed with revulsion and horror when those little legs are moving on one's skin. So, too, from the fact that one sincerely believes that it is really not so important to protect oneself, it does not follow that one has managed to "silence" the self's demand for protection; it does not follow that one has overcome the insidious influence this demand has on one's assessments of the reasons pro and con..$^{57}$

It is one thing to acknowledge that in the scheme of things I am not all that important. It is another thing altogether to experience this conviction emotionally - as I experience my fear and self-love. If my belief in my insignificance remains detached from my emotions, it is unlikely to counteract the emotional influence of my fear and self-love. It is unlikely to determine how I weigh the reasons for and against sticking my neck out. It is unlikely to play a decisive role in how I apply what I know.

This is an important challenge to my hope that I could moderate my self-love by reminding myself (over and over) of the important sense in which I am really not much to fuss about. Before I pursue this challenge any further, however, I want to consider a problem posed by the content of the attitude I am here recommending. This is a problem faced by any precept that stresses the unimportance (even the unreality) of "the self"58: if we were to succeed in seeing ourselves from the point of 
view of the universe, how could we consistently refrain from seeing others this way as well? And if they, too, are not really all that important, then why make such a fuss about how they are treated? Can I consistently adopt the perspective I am here recommending without thereby taking the very perspective that is associated with those who wield power in the most unjust and inhumane regimes? What distinguishes (i) someone who has freed herself from an unjustified attachment to herself from (ii) someone like Harry Lime in The Third Man, who, looking down from the top of a Ferris wheel, compares the people below to dots, and avows that it would make no difference if some of them "stopped moving forever"? 59 Of course, someone who exemplifies the sort of "humility" Murdoch champions when she urges us to admit that we are rather "small," not terribly "interesting," creatures ${ }^{60}$ will not have any of the most common motives for subjugating her fellow human beings. (She will not be moved by the lust for power or wealth or recognition.) But the conviction that no human life really matters much would seem to be motivation enough for treating unaccommodating human beings as impediments to be pushed to the side -- or removed. ${ }^{61}$

There are passages in The Sovereignty of Good that come frighteningly close to sounding like something that could be endorsed by one of today's radical jihadists. We should, Murdoch says, cultivate "an attention which is ... an attempt to look right away from self towards a distant transcendent perfection, a source of uncontaminated energy, a source of newand quite undreamt-of virtue. This attempt, which is a turning of attention away from the particular, may be the thing that helps most when difficulties seem insoluble, and especially when feelings of guilt keep attracting the gaze back towards the self. This is the true mysticism which is morality." To be sure, Murdoch concedes that this mysticism is "perhaps ... difficult and easily corrupted." 62 But she does not seem to take this possibility as seriously as she should. We, at any rate, should ask ourselves how "turning away from the particular" self is compatible with a commitment to human rights. How, we should ask, can we keep our eyes on the imperfect human beings who are bound 
with us to this earth, while at the same time gazing at a distant transcendent perfection?

Murdoch insists that attending to reality unencumbered by the distortions of selflove is inseparable from attending to other human beings with love and compassion. She is right, of course, that it is far easier to care about others when one is not preoccupied with one's own needs and desires. But how can it make sense to care about others if "'All is vanity' is the beginning and end of ethics"? ${ }^{63}$ What does it mean to be virtuous if "nothing in life is of any value except the attempt to be virtuous"? ${ }^{64}$ According to Murdoch, "the humble man, because he can see himself as nothing, can see other things as they are. He sees the pointlessness of virtue and its unique value and the endless extent of its demand."65 There is something deeply right about this -- something partly captured by my critical response to the significance Sereny and Arendt attribute to the prospect of beneficial consequences. And yet, ...

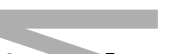

The issue I am raising here might seem to support the suggestion that in stressing my own insignificance, I have taken things a bit too far. It might seem that the lesson I should draw from the moral exemplars is simply that I do not matter more than anyone else. As my remarks about utilitarianism suggest, however, I do not think that the moral hazards that concern me here can be adequately addressed by strengthening my egalitarian impulses. To be sure, if we have a "moral sense," then our interactions with others will reflect our understanding that we are not more important than they are. But the point of turning for guidance and inspiration to human beings who are braver than we are -- or, to speak only about what I know, braver than I am -- is precisely that though the fact that I am no more important than anyone else appears to support certain principles of justice, it does not appear to support any uncontroversial, determinate conclusions regarding how I should weigh the importance of defending these principles against the importance of protecting myself. Appreciating the moral equality of all human beings seems to be perfectly compatible with being clueless about when any one of us is morally

This article is protected by copyright. All rights reserved 
obligated to stick her neck out -- especially if we grant that respect for the equal value of all persons should not be given a consequentialist interpretation.

Perhaps I am mistaken about this. But even if I were convinced that we can get more moral mileage than I think we can out of the fact that all human beings are equallyimportant -- and even if we can get more mileage out of feelings of solidarity or feelings of love and compassion for humanity -- I would still believe that the exercise of trying to see myself as a tiny dot in the universe is of great moral value. Many religious rituals are exercises of this sort. And those of us with no faith in the supernatural must find other ways to confront and affirm the significance of our insignificance.

But this brings me back to the apparent difficulty of reconciling any such affirmation with the conviction that all those other human dots really matter -- a lot. I realize that things can matter in many different ways. My question is: are the ways I think human beings really matter independent of the ways I think they do not? Perhaps it is possible to press the sort of point that is often made against the consequentialists. The fact that it is wrong to kill another human being, we are reminded, does not imply that it is wrong to refrain from "bringing" another human being "into the world." Why assume, then, that if it is wrong to kill another human being (or deprive her of basic civil liberties), this must be because it matters whether -- and if so, when -- this being departs from the earth?

This is not a rhetorical question. I need to give it more thought. In particular, I need to better understand what I have to assume about the ground of moral obligations in order to assume that I can consistently hold the two attitudes I am considering here. In other work I have argued that we are justified in treating human beings as constraints on what we have reason to do even though they are not ends in themselves. ${ }^{66}$ Rather than rehearse these arguments here, I will simply note that I can respect the power and authority of reason -- my own and others -- precisely because I regard the capacity to reason as a uniquely powerful means to 
determining what is important, justifiable, and good. If, moreover, I respect the authority and power of reason, then I cannot consistently dismiss what other reasoning beings have concluded about what I and they have reason to do.

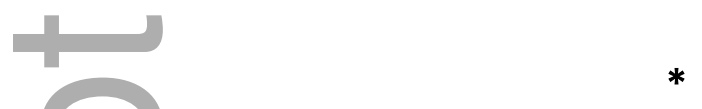

The suggestion that we have reason to treat one another as "ends in ourselves" even if we are not really ends in ourselves is addressed to the concern I raised about the consistency of believing both that there is a sense in which no human being is all that important and that there is another sense in which every human being is very important, viz, every human being has a claim to be treated as valuable beyond price. Again, I need to give this issue more thought. At this point, however, I want to set it aside. I want to shift my attention to the fact that even if I cannot consistently hold both beliefs at once, this incoherence might not be an insurmountable psychologicalimpediment. Though there are obvious costs to incoherence, there are sometimes also very significant benefits. ${ }^{67}$ Given the importance of the benefit I am here discussing, I thus want to consider whether it is psychologically possible for me to cultivate a profound indifference to my own fate even while remaining wholeheartedly committed to basic civil and human rights.

Note that even those who insist that I am mistaken to regard myself as not very important could agree that it is at least sometimes desirable for me to maintain this false self-conception - that this is desirable, when, for example, it makes me less likely to discount the needs and interests of others. In short, even if the apparent incoherence to which I am here calling attention is a reason to reject the attitude toward oneself that I am championing here, we could still have reason to live with this incoherence, if it is possible for us to do so.

Is this, in fact, possible? In Fear and Trembling Kierkegaard's pseudonym Johannes de Silentio addresses a very similar question when he describes the awe-inspiring balancing act performed by the "knight of faith." The knight of faith, he explains, lives every moment of his life in relation to a transcendent point of view. Yet, at the

This article is protected by copyright. All rights reserved 
same time, he is fully invested in all aspects of his life in a way that requires him to be in no way detached from this investment.

De Silentio confesses that he does not see how this is possible. ${ }^{68}$ Like Thomas Nagel in "The Absurd," 69 he wonders how anyone can occupy a point of view from which he is at the same time detached. The difficulty seems to have something to do with the necessary conditions of acting for reasons. No one can deliberate about what to do without taking it for granted that her commitments matter; no one can assume that her commitments matter without assuming that she has good reason to try to fulfill them; no one can assume that she has reason to fulfill her commitments, without assuming that it matters what she does; and no one can assume that it matters what she does without assuming that she really does matter herself. Still, as I said, not all ways of mattering are the same. And even if de Silentio is justified in wondering whether someone who is wholeheartedly invested in the goals she pursues can simultaneously believe that it matters very little whether she achieves these goals, I am inclined to think that this is because the two attitudes at issue here are in express opposition to each other. In contrast, there is no such transparent conflict between (i) believing that human beings are worthy of concern and respect and (ii) believing that it is really no big deal if they die. I am thus inclined to believe that someone can maintain both beliefs at once, even if in so doing she would not be fully coherent.

Of course, it would be much easier for someone to do this, if the "no big deal" belief lacked emotional reality. In this case, she would be like the airline passenger who believes that she is perfectly safe even as she is terrified of crashing. Yet if one's belief in one's insignificance lacked emotional reality, could it really counteract the effects of fear and self-love? The example of the airline passenger suggests that this might be possible. (After all, her belief in her safety may well enable her to act as she would if she were not the least bit afraid.) Still, as I earlier noted, a powerful emotion is less likely to have a morally corrupting effect on someone if she experiences an equally powerful countervailing emotion. 
For this reason, I want to return to the challenge I raised and set aside a few pages earlier: is it possible for a healthy human being to feel that she is not terribly important -- to feel this in a way that can influence which facts she considers in deciding what to do, and what significance she attributes to these facts? Could I feel the truth of my own insignificance in the same way that my fear forces me to feel how really, really important it is for me to protect myself against loss of life, liberty, and livelihood? More carefully: could my belief in my insignificance have emotional reality without my suffering the enervation of depression or despair? ${ }^{70}$

There appears to be evidence that this is, indeed, possible. Unfortunately, this evidence also suggests an additional reason for me to be wary: not only does the content of the attitude I am here exploring appear to be in tension with my moral convictions; it also seems that the power this attitude has to influence my reasoning is in tension with my reason for cultivating it, viz., that by so doing, I will gain the courage necessary to see what my moral convictions imply. Insofar as I experience the truth of my insignificance in a way that is energizing rather than enervating, I seem to have a motive for nurturing this experience that is also a motive for discounting the claims of my fellow human beings.

To see what I have in mind, one need merely consider how deeply emotionally satisfying it can be to transcend one's own limitations. It is liberating to detach oneself from the sort of cares and concerns that are the stuff of most human lives. There is something exhilarating about setting aside one's small preoccupations in the service of something bigger than oneself. There is something invigorating in risking one's life. This means that precisely insofar as the indifference-cummodesty/ modesty-cum-indifference I have here been exploring has sufficient emotional power to be a countervailing force to fear and self-love, it also has the potential to be valued for its own sake. And this means that anyone who cultivates this attitude acquires a motive for joining ranks with those who encourage her to 
seek the emotional satisfaction of self-transcendence at the expense of human beings and their quotidian cares and concerns.

This is the danger to which Shulman and Camus alert us when they warn that "it is a disaster to be righteous" and to be so "stiffly" committed to a greater good that one's willingness to die for this good becomes a willingness to kill. If becoming brave enough to take the sort of risks I have been discussing here involves developing a disposition to shrug one's shoulders at the demands of the self, then in becoming brave enough to take these risks, one runs the very different risk of shrugging one's shoulders at one's own humane impulses. In short, insofar as the courage of one's convictions depends on loosening one's attachment to oneself, it is vulnerable to morphing into the courage to overcome one's convictions. ${ }^{71}$

Karl Ove Knausgard makes just this point when he discusses the war lust in Germany both during the lead up to WWI and after the war, during the rise of Nazism:

Wagner, Hoelderlin, Rilke, Hofmannsthal, George, all those writers and poets cultivated by German youth, celebrated the great, the divine, the essential, and they lauded death, too, which lay beyond it all. Stirb und Werde, die and become - something to die for means something to live for. The people, the earth, the war, the hero, death. ${ }^{72}$

Wagner's tales of heroism, his great storms of emotion, are to do with... exaltation and the transcending of the self. The I of Mein Kampf expresses itself in terms of the same model, elevating war and the singular life of the self to something untainted by the quotidian, a hallowedness meaningful in itself. ... ${ }^{73}$

Inspired by a Paul Celan poem, ${ }^{74}$ Knausgard identifies (i) the desire to devote oneself to something greater than one's own little existence with (ii) a contempt for 
the needs and demands of an ordinary human life. It is, he points out, difficult to exalt in transcending the everyday, without ceasing to commune with real human beings -- ceasing, that is, to see each human being as an individual 'you,' who must be addressed as such. This is the key to the moral bankruptcy of Hitler's Mein Kampf. it "contains no 'you,' only an 'I,' and a 'we,' which is what makes it possible to turn 'they' into 'it.'"'75

Knausgard reminds us that a lack of concern and respect for other human beings is inseparable from a lack of respect for reason. As Kant explains, ${ }^{76}$ reasoning requires an openness to correction from other reasoners; and this requires taking their points of view seriously, and living with them in a way that acknowledges this fact. In this paper I have been focusing on how difficult it can be for us to do this under conditions in which acknowledging the claims of others requires us to put ourselves in danger. My recent reflections on the emotional satisfaction of overcoming selflove complicate this story by calling attention to the fact that our capacity to reason can be threatened from the other direction as well. Not only may it be impossible to reconcile (i) the conviction that there is an important sense in which no human being is all that important with (ii) the conviction that one ought to treat one's fellow human beings as ends in themselves; it also seems that -- considerations of coherence aside -- the very lack of self-concern that can enhance our capacity to see things aright is capable of blurring our moral vision.

This is where my anxious musings have led me. On the one hand, my capacity to reason does not suffice to enable me to draw the moral distinctions that have preoccupied me from the beginning of this paper. It seems, moreover, that when I have good reason to be afraid of what will happen to me if I stand up for my ideals (and for the human beings whose rights are affirmed in these ideals), I would be more likely to consider the things that I should consider, and to give these considerations their proper weight, if I were disposed to take myself much less seriously than I do now. On the other hand, if my lack of self-concern were powerful enough to be a source (or constituent?) of courage, it would seem to be powerful 
enough to be morally corrupting. Though I continue to believe that a profound sense of my own insignificance is an element of practical wisdom, I also concede that acquiring a stronger disposition to transcend the demands of my precious self would render me more vulnerable to privileging abstract ideals over concrete human beings.

These reflections leave me uneasy. Yet I continue to believe that it must be possible to live with the tensions I have identified here. Indeed, it seems to me that this is what so many moral exemplars exemplify. Their ability to maintain both (i) the attitude expressed in the thought: "the risk I run is really not such a big deal" and (ii) the attitude expressed in the thought: "the stakes for which I run this risk could not be higher" is an essential component of their moral decency. This is the ability they express when they privilege doing what they can over spending time and energy trying to determine what they can justify doing.

Among the moral exemplars to whom I have turned for guidance and inspiration is Camus's Dr. Rieux. It is impossible to capture with a few citations the dispassionate -- almost chilly -- detachment with which Rieux regards his fellow townspeople. In contemplating what will happen to them if they are struck by plague, he knows that "since a dead man has no substance unless one has actually seen him dead, a hundred million corpses broadcast through history are no more than a puff of smoke in the imagination."77 He knows, too, that "any victories [over the plague] will never be lasting"; the plague means "a never ending defeat."78 Yet this clear vision notwithstanding, Rieux is committed to doing all he can to save lives. And he carries on this fight with a compassion and pity that his growing exhaustion never fully extinguishes. Having mastered the art of learning how to die, Rieux continues to care about the living. He does not try to resolve this tension in his point of view. In this way he is able to risk his life daily in order to avoid accommodating the powerful forces that are indifferent to the value of humanity. 
Before the plague "crashed down on their heads from a blue sky,"79 the people of Oran were "like everybody else, wrapped up in themselves"; they "disbelieved in pestilences." "They went on doing business, arranged for journeys, and formed views. How should they have given a thought to anything like plague, which rules out any future, cancels journeys, silences the exchange of views?"80 Rieux notes that these people were not to blame for their self-absorption. Yet after the arrival of plague, everything changed. It was now up to everyone "to do what they could to fight it." "The unthinkable thing would have been not to have brought themselves to [fight]." Of course, those who saw things this way could also see "quite clearly a point that could be made against [them], which is that [they] were risking their lives." But they also believed that this was beside the point. "[T]he question [was] not of knowing what punishment or reward [would result]." "[T]he question was whether or not plague was in their midst and whether or not they must fight it." ${ }^{81}$

This is the question that has haunted me since November 9, 2016. I am haunted by my uncertainty about the conditions under which an affirmative answer to the first question ("Yes, I am living in the midst of a plague") supports an affirmative answer to the second ("Yes, I must fight it"), and by my uncertainty about what an affirmative answer to the second question would require me to do. Unlike such moral exemplars as Rieux, I find these questions to be very difficult to answer. I do not know how to answer them; and from what I can tell, I am in good company. Even when the plague that ravishes a community is a bodily illness, and its mechanism is perfectly well understood, many of the people living in that community will be filled with doubt about what they should do in response. Rieux's assertion to the contrary notwithstanding, even when it is obvious what needs to be done in order to prevent the disease from spreading, knowing which risks one must take in order to avoid being a part of the problem is almost never as simple as knowing that $2+2=4.8283$

The moral challenge is far greater when the "plague" is a complex system of injustice. On many occasions, surely, one is not doing anything wrong if one makes 
the best of the fact that one is trapped in such a system. But on other occasions, such accommodation cannot be justified, even though there is no other reasonable means of protecting oneself and the people one loves. Awaking on November 9, 2016, I suddenly felt the importance of being able to distinguish the permissible from the impermissible accommodations. And I suddenly felt the dread of realizing that I do not know where the boundary lies. Ever since, I have been thinking of all those people who are at this very moment living under regimes that deny them the most basic rights -- people who plant their gardens and gather in the evening with friends, putting up with a situation that is not only very bad, but very, very wrong. I think about what these people do and what they do not do. I wonder what I would do in their place. I try to accept the fact that I may never know what I should do -not even if one day my luck is no better than theirs. ${ }^{84}$

\section{Sarah Buss}

University of Michigan

sbuss@umich.edu

${ }^{1}$ I take this advice as a counterbalance to talk of the importance of "standing up to" "those in power." The poem ends with an ellipsis. And its final lines are especially relevant to my reflections on the danger of devaluing the quotidian: "There is so very much death, and that is why affection/for pigtails, bright-colored skirts in the wind, for paper boats no more durable than we are...." (Czeslaw Milosz, "Counsels," New and Collected Poems: 1931-2001(New York: HarperCollins Publishers, 1988), pp. 237-38.

${ }^{2}$ Cheshire Calhoun enumerates the sorts of costs that are relevant to my inquiry: "contempt, ostracism, loss of a job, penal sanctions, the breakdown of friendships and familiar relations, being labeled 'confrontational,' 'difficult,' 'overly sensitive,' or 'militant,' not to mention the inexhaustible confidence of others that one is wrong." These, she notes, are "public obstacles to integrity." (Cheshire Calhoun, "Standing for Something," The Journal of Philosophy 92, no. 5 (1995): 259.)

${ }^{3}$ One well-known example concerns two Polish poets: Zbignew Herbert refused to work for communists; took menial jobs instead; Czeslaw Milosz was a cultural attaché before finally defecting in Paris. Milosz's refusal to take part in the Warsaw uprising also speaks to the issues of tactics and consequences I address later: he 
was convinced that the uprising was pointless -- and he believed that he could do more to support the ideals in which he believed by preserving his life so that he could write poetry.

${ }^{4}$ I wrote this paper with no thought whatsoever of a paper I had written almost ten years ago on the obligation to resist oppression. Having rediscovered this old paper when I was putting the finishing touches on this one (I was looking for something else!), Ireread it and was surprised to see that it begins with a question that is very similar to the one I am grappling with here. Despite this fact, there is very little overlap. In fact, I spend much of the paper raising questions about Thomas Hill's broad claims that "it is each person's moral task to identify and take whatever steps he or she can to oppose and eliminate oppression" and it is "easy to see that continuing to be a bystander when one can protest and do something about oppression would [always] be to fail to respect its victims." In so doing, I identify reasons not to resist oppression, whether one is a victim or a bystander. (Sarah Buss, "Reflections on the Responsibility to Resist Oppression," Journal of Social Philosophy 41, no. 1 (Spring, 2010), p. 40, p. 44) Other important differences between that paper and this one include the fact that my interest in the topic was not nearly so personal then as it is now, and I was not especially focused on the sort of costs that inspire reasonable fear. Interestingly, however, I make some remarks at the end that could serve as a set up for my present musings. Here is the beginning of the final paragraph: "I share Hill's conviction that, whatever our first-order moral obligations may be, we have second-order duties to do what is necessary to increase our capacity to recognize and fulfill these obligations. I believe, in particular, that we are morally obligated to grapple with the difficult question of reasonable costs. This is surely a central issue in any good-faith attempt at self-scrutiny."(p. 48) And here are the concluding sentences: "It is certainly important to keep asking ourselves what we are obligated to do to resist oppression. It may be, however, that this is not a question we can answer to our own satisfaction unless our sense of balance has made the weighing of pros and cons come to seem merely 'academic."'(p. 48)

${ }^{5}$ See Plato, The Gorgias 469a-479e, trans. by W.D. Woodhead, in Collected Dialogues, ed. by Edith Hamilton and Huntington Cairns (Princeton: Princeton University Press, 1963), pp. 229-307.

${ }^{6}$ For those who would like to consider a recent case, I recommend a New York Times special report on the rein of ISIS in Mosul. ("The Isis Files," The New York Times (April 8, 2018): 2-11) The report chronicles the "collaboration between the militants and the civilians under their yoke." It focuses, in particular, on the Chief Technical Supervisor from the Iraqi agricultural department who -- in order to avoid the deadly wrath of those in power -- facilitated the process whereby Sunni farmers appropriated the land of Shias: "With the stroke of his pen, farmer's lost their ancestors' cropland, their sons were robbed of their inheritance and the wealth of entire families, built up over generations, was wiped out." (8)) 
${ }^{7}$ Hannah Arendt, “Personal Responsibility Under Dictatorship," in Responsibility and Judgment (New York: Random House, Inc., 2003), p. 47.

8 Ibid., p. 18.

${ }^{9}$ See the movie Divided We Fall for an exploration of how complicated this "weighing" can be. The main character in this movie is moved by sympathy and kindness to hide a Jew from the Nazi's who are occupying his small Czech town. Though he has no compunction about keeping his head down in order to avoid antagonizing these occupiers, he cannot bring himself to turn his back on a hunted human being (and old friend of the family) in need. Having done so, he then must actively assist the occupiers in order to throw them off the scent. (See also note 3.)

${ }^{10}$ Arendt, "Personal Responsibility Under Dictatorship," p. 25.

${ }^{11}$ In other words, she is not talking about "clear-eyed akrasia."

${ }^{12}$ I explore a related issue in an earlier paper when I discuss the relation between our personal projects and our obligations to people in need. (See "Needs (Someone Else's), Projects (My Own), and Reasons," The Journal of Philosophy 103, no. 8 (August 2006): 373-402))

${ }^{13}$ In focusing on the corrupting effect of fear, I am, in effect, suggesting that things are more complicated than Epictetus suggests when he advises: "Let death and exile and everything that is terrible appear before your eyes every day, especially death; and you will never have anything contemptible in your thoughts or crave anything excessively." (See Epictetus, Handbook of Epictetus, section 21, trans. by Nick White (Indianapolis: Hackett Publishing Co. , 1983], p. 16.) Later in this paper, however, I explore the value of a kind of Stoic detachment from one's own life. (See also my discussion of Admiral Stockdale, pp. 22-23.)

${ }^{14}$ Wiggins, David, "Incommensurability: Four Proposals," in Needs, Values, Truth: Essays in the Philosophy of Value (Oxford: Oxford University Press, 1987), p. 372. ${ }^{15}$ Joseph Conrad, Lord Jim (Garden City, New York: Doubleday \& Co., Inc., 1920), p. 37.

${ }^{16}$ Ibid., p. 112. "The fear, the fear," he continues, "look you -- it is always there... " "And even for those who do not believe this truth there is fear all the same -- fear of themselves."

${ }^{17}$ Ibid., p. 79.

${ }^{18}$ Ibid, pp. 31-32.

This article is protected by copyright. All rights reserved 
${ }^{19}$ Robert Adams, Finite and Infinite Goods: A Framework for Ethics (Oxford, Oxford University Press, 1999), p. 220.

${ }^{20}$ Gopnik, Adam, “The Takeback," The New Yorker (April 8, 2019), p. 82.

${ }^{21}$ Conrad, Lord Jim, p. 21.

${ }^{22}$ As Thomas Nagel notes, "even if ... individual morality can operate under the most monstrous of coercive institutions, that does not mean that it is our only, or even our chief, moral resource. Other coercive institutions, such as due process of law, can themselves embody morality - and in a way that relieves the pressure on individual morality.... " (Thomas Nagel, "A Gruesome Ghost Dance," The New York Review of Books (Sept. 28, 2017): pp. 8-9.)

${ }^{23}$ Since beginning to worry about this issue, I have been reminded that it was not that long ago -- during Woodrow Wilson's administration -- that the U.S.

government organized and approved significant assaults on the civil liberties of U.S. citizens. For a highly informative (and very disturbing) summary, see Adam Hochschild's "When Dissent Because Treason," The New York Review of Books (September 27, 2017): 82-85. Hochschild quotes Wilson's warning that "there are citizens of the United States, I blush to admit, born under other flags.... who have poured the poison of disloyalty into the very arteries of our national life... . Such creatures of passion, disloyalty, and anarchy must be crushed." As Hochschild notes, "A somber lesson offered by the events of 1917-20 is that when powerful tensions roil the country, and hysteria fills the air, rights and values we take for granted can easily be eroded: the freedom to publish and speak, protection from vigilante justice, even confidence that election results will be honored." By the time World War I was over, more than seventy-five different publications had been either censored or completely banned. Thousands of people had also been arrested for leftist or labor union activities of one sort or another, and vigilante anti-labor and anti-communist groups were encouraged to do their worst.

${ }^{24}$ One good place to start is Susan Neiman's "Enlightenment Heroes," in Moral Clarity: A Guide to Grownup Idealists (Princeton: Princeton University Press, 2009), pp. 381-21. See also the work cited in notes 39, 47, and 69.

${ }^{25}$ David Shulman, Dark Hope: Working for Peace in Israel and Palestine (Chicago: University of Chicago Press, 2007), p. 312.

${ }^{26}$ See Vanessa Carbonell, "The Ratcheting-Up Effect," Pacific Philosophical Quarterly 93, no. 3 (2012): 228-54 and Shelly Kagan, The Limits of Morality, (Oxford: Oxford University Press,1989).

${ }^{27}$ For some comments on the role of anger in resisting injustice, see The Moral Psychology of Anger (London: Rowman \& Littlefield, 2017); Macalaster Bell, “Anger,

This article is protected by copyright. All rights reserved 
Virtue and Oppression" in Feminist Ethics and Social and Political Philosophy: Theorizing the Non-Ideal, ed. by Lisa Tessman (London: Springer, 2009), pp. 16383; Amia Srinivisan, "The Aptness of Anger" Journal of Political Philosophy 26, no. 2 (June, 2018): 123-44.

${ }^{28}$ Shulman, Dark Hope, p. 316. Later I will address the moral dangers posed by this sort of motive when it is not conditioned by the sort of "moral sense" I mention in the following paragraph.

${ }^{29}$ Ibid., pp. 316-17.

${ }^{30}$ Albert Camus, The Plague, trans. by Stuart Gilbert (New York: Random House, 1972), p. 195.

${ }^{31}$ Arendt suggests another reason why we might try to rely less on our reason in such cases. When people live under a regime that denies them the freedom to express their opinions -- and to work together to promote values they hold dear -their ability to reason is itself in danger. (See Arendt, "Thinking and Moral Considerations: A Lecture," Social Research 38, No.3 (Autumn 1971): 417-46. Given this fact, abandoning the attempt to reason one's way to determining whether one is justified in accommodating injustice may be the best means to the end of shoring up the capacity to reason -- one's own and that of one's fellow citizens. (Calhoun makes a point similar to Arendt's when she notes that "social circumstances that erect powerful deterrents to speaking and acting on one's own best judgment undermine the possibilities for deliberating about what is worth doing." (Calhoun, Standing for Something," Journal of Philosophy 92 (May 1955): 235-60.) See also the citation from Kant in note 76 .)

${ }^{32}$ Conrad, Lord Jim, p. 38.

${ }^{33}$ There is an extensive literature on the significance of making sacrifices one thinks will make no difference. See, e.g., Shelly Kagan, "Do I Make a Difference?"

Philosophy and Public Affairs 39, no. 2(2011):105-141; Julia Nefsky, "How you can help, without making a difference" Philosophical Studies 174, no. 11: (2017): 27432767; Alan Carling, "The Paradox of Voting and the Theory of Social Evolution," in Preferences, Institutions and Rational Choice, ed. by Keith Dowding and Desmond King (Oxford: Oxford University Press,1995), pp. 20-43; Mark Budolfson, "The Inefficacy Objection to Consequentialism and the Problem of the Expected Consequence Response," Philosophical Studies 176, no. 7 (2019): 1711-1724; Eliot Michaelson, "A Kantian Response to Futility Worries" in Food, Ethics, and Society, ed.by Anne Barnhill, Mark Budolfson, and Tyler Doggett (New York: Oxford University Press, 2017, pp. 215-18.

${ }^{34}$ David Shulman, in a talk at a conference on "Truth and Beauty," The Einstein Forum (June, 2018)

This article is protected by copyright. All rights reserved 
35 James Stockdale, “Courage Under Fire: Testing Epictetus's Doctrines in a Laboratory of Human Behavior," (a speech delivered at the Great Hall, King's College London, November 15, 1993) (Hoover Institution on War, Revolution, and Peace, 1993), p. 9.

36 Ibid., p. 15.

${ }^{37}$ Ibid., p. 17.

38 Ibid., p. 17.

${ }^{39}$ Ibid., p. 15 It is perhaps worth noting that when Stockdale was caught with information that could be used to force him to incriminate others, he tried to commit suicide.

40 Victor Klemperer's diary is full of examples of people who strived mightily to accommodate the regime in almost all ways and yet also defied the regime in other ways. Klemperer himself did all he could not to rock the boat, and yet refused to raise his arm in greeting -- not in open defiance (he hoped no one would notice), but in defiance, nonetheless. It is worth adding that though he welcomes every small act of resistance, he also concedes that even if "a million and more" citizens act similarly, these acts will have no impact "at all against the prodigious organization and unscrupulousness and power of the government." (p. 214) Stockdale acknowledges the same thing about the small acts of defiance he describes. For more on the moral significance of efficacy, see pages 31-33.

${ }^{41}$ Here, I think, it is worth citing a cautionary remark from Kierkegard (expressed, at the end of Either/Or by one his pseudonyms): "Ought I to admire ... the searching consciousness which scrutinizes itself and then comes to the comfortable conclusion that one does what one can? Would it be so easy a thing for you, my hearer, to determine how much it is one can? Were you never in such danger that almost in despair you exerted your strength to the utmost and yet ardently wished you could do more? And perhaps another man was watching you with a dubious and beseeching look, wondering if you might not do more. Or were you never alarmed about yourself, so much alarmed that it seemed to you as if there were no sin so black, no selfishness so odious, that it might not sneak into you and as a foreign power gain mastery over you? Did you never sense this dread? For if you never sensed it, then do not open your mouth to reply, for you are unable to answer the question here put to you. But if you have sensed this dread, then, my hearer, I ask you, Did you find repose in that saying: One does what one can? .... Was not this precisely the reason for your disquietude [when you have seen other men "tottering to whom you were wont to look up to with trust and confidence"], that you did not know within yourself how much it is a man can do, that at one moment it seemed to you so infinitely much, at another so very little? Was it not for this 
reason your anxiety was so painful, that your soul could not penetrate your consciousness, that the more earnestly you desired to act, the more heartily you wished to, so much the more dreadful became the duplicity in which you found yourself involved, wondering whether you may not have done what you could or whether you had done what you ou could, but no one came to your aid?" (Kierkegaard, Soren, Either/Or, Part II, trans. by Walter Lowrie, "Ultimatum" [Princeton: Princeton University Press, 1987], pp. 346-47.)

42 Perhaps, this is why it is tempting to say, with Aristotle, that under the relevant circumstances, these exemplary human beings are less afraid than most others. They are afraid insofar as they have the experience as of being in danger. Yet they do not regard this experience as the key to what is really, really important. "He will be called brave," Aristotle writes, "who is fearless in face of a noble death, and of all emergencies that involve death; and the emergencies of war are in the highest degree of this kind." (See Aristotle, Nicomachean Ethics, trans. by W.D. Ross, Book III, Chapter 6, in The Basic Works of Aristotle, ed. by Richard McKeon (New York: Random House, 1841), p. 975.)

43 See John McDowell, "Virtue and Reason," in Mind, Value, and Reality (Cambridge: Harvard University Press,1998), pp. 50-76.

44 See Mark Johnston, Surviving Death for a thought-provoking defense of the view that "there is no general normative fact that says: You must take the bodily envelope to be the boundary of personal identity, and hence as the focus for self-concern, on pain of being out of joint with reality."(Mark Johnston, Surviving Death (Princeton: Princeton University Press, 2010), p. 244) According to Johnston, people who do not "identify with the interests" of other "personalities" must "practice worthless detachment" (p. 375) in order to avoid regarding death as a significant loss. In addition to being skeptical about the possibility that the focus of my self-concern could extend to others in the way Johnston describes, I worry about the moral implications of this recommendation. I cannot engage with these vexed issues here. I hope, however, it will be clear why I believe that practicing a certain sort of detachment from self is far from "worthless." (p. 244)

45 For an interesting discussion of one sense in which a person's life is not important, see Susan Wolf, “Good for Nothing," Presidential Address delivered before the One Hundred Seventh Annual Eastern Division Meeting of The American Philosophical Association in Boston, Massachusetts, on Wednesday, December 29, 2010.

${ }^{46}$ As Stockdale notes: it is the stoic lesson too. Being disposed to do the right thing is, he insists, inseparable from being profoundly indifferent to "your body, property, wealth, health, life, death pleasure, pain, reputation." (Stockdale, Courage Under Fire, p. 9.) 
${ }^{47}$ See Socrates's proposal regarding how the Athenians should punish him. (Plato, Apology 36b-d,, trans. by Hugh Tredennick, in Collected Dialogues, pp. 3-26)

${ }^{48}$ Nadezhda Mandelstam's description of her husband, the poet Osip Mandelstam, provides us with another illustration of the attitude I am hear trying to describe. Osip, she explains, was "uncompromising: what a pity this was not a quality that could be doled out to others." (Nadezhda Mandelstam, Hope Against Hope, trans. by Max Hayward (New York: Random House, 1970), p. 233) Importantly, like Socrates, his moral courage was inseparable from a stance that was not essentially moral. It reflected his "rejection of the commonplace image and the hackneyed phrase by which meaning is obscured." Osip Mandelstam was dedicated to creating "an art that faithfully recorded life and living events, as opposed to all that was deathlike." (p. 269) It was this dedication that cost him his life.

${ }^{49}$ Iris Murdoch, The Sovereignty of Good (New York: Routledge \& Kegan Paul, 1970), p. 100.

${ }^{50}$ Arendt, "Personal Responsibility Under Dictatorship," p. 45.

${ }^{51}$ Gita Sereny, Into That Darkness: An Examination of Conscience (New York, Random House, 1974), p. 364.

52 Ibid., pp. 231-32.

${ }^{53}$ Hannah Arendt, Eichmann in Jerusalem: A Report on the Banality of Evil (New York: Viking Press, 1963), pp. 232-33.

${ }^{54}$ Hannah Arendt, "Personal Responsibility Under Dictatorship," p. 44. In some places, Arendt appeals to efficacy, not as a condition on whether someone has reason to resist, but as a valuable side-effect of being willing to resist even if one is not confident that this will make a difference. If, she reasonably suggests, people did not treat the likely efficacy of their acts of resistance as a decisive consideration, there would be far fewer unjust regimes. ("Imagine," she asks more than once, "what would happen to any of these forms of government If enough people would act "irresponsibly" and "refuse support."(p. 47) See also Hannah Arendt, Eichmann in Jerusalem: A Report on the Banality of Evil (New York: Penguin Books, 1963),p.

233)

${ }^{55}$ In her study of oppression, Ann Cudd says that for an act to count as "resisting oppression," it has to reflect "an intention to lessen the oppression" (Ann Cudd, Analyzing Oppression (Oxford: Oxford University Press, 2006), p. 191) Shortly after making this statement, however, she adds that it is enough that the act is "intended as a case of resistance"(p. 191). And her considered view appears to be that "it has to be possible for the act of resistance to effect the long-term or overall lessening of oppression, or at least to send a message of revolt to the oppressors" ( $p$.

This article is protected by copyright. All rights reserved 
$192)$-- or, as she later puts it, "a message of revolt or outrage" (p. 193). (Does expressing such a message suffice for sending it? Does sending it to a low-level functionary of the regime suffice for sending it to the regime itself? I am not sure what Cudd's views are on these points. She does say, however, that if one could not participate in a strike without being interpreted as "shirking"(p. 199) -- because one was acting all alone -- then it makes no sense to strike.

${ }^{56}$ Sereny reports her conversations with a few of the Jews who were forced to help dispose of the bodies and sort clothes and goods in Treblinka. The choices they had to make are impossible for me to fathom. Having done all they could to stay alive, and sensing that their time was running short, they gradually began organizing a revolt/escape that would involve all the prisoners. The history of this plot and its botched execution offers a powerful example of the sort of trade offs Adams mentions - between biding one's time and risking everything. (Hundreds of prisoners were shot in the camp. Most who made it out were also shot. The organizers were the last to attempt to escape. Every one of them died.)

${ }^{57}$ For some discussions of recalcitrant emotions, see Michael Brady, "Recalcitrant Emotions and Visual Illusions," American Philosophical Quarterly44, no. 3 (July, 2007): 273-284; Christine Tappolet, "Emotions, Perceptions, and Emotional Illusions," in Perceptual Illusions. Philosophical and Psychological Essays, (London: Palgrave Macmillan, 2012), ed. by Calabi Clotilde (2012): pp. 205-22; Hagit Benbaji, "How is Recalcitrant Emotion Possible?" Australasian Journal of Philosophy 91, no. 3 (2013): 577-599.

${ }^{58}$ For some comments on the Buddhist views about the self, see Jiri Benovsky, "Buddhist philosophy and the no-Self view" Philosophy East and West 67, no. 2 (April,2017): 545-53; Mark Siderits, “The Importance of 'My' Being Single: A Response to Jiri Benovsky," Philosophy East and West 67, no. 2 (April, 2017): 55358; Mark Siderits, Evan Thompson, Dan Zahavi (eds.), Self, No Self? Perspectives from Analytical, Phenomenological, and Indian Traditions (Oxford: Oxford University Press, 2010); Monima Chadha and Shaun Nichols, "Self-Conscious Emotions Without a Self" Philosophers' Imprint 19, no. 28 (2019): 1-16.

59 The Third Man, 1949, directed by Carol Reed. Story by Graham Green and Alexander Korda. Screenplay by Orson Welles, Carol Reed, and Graham Greene.

${ }^{60}$ Iris Murdoch, The Sovereignty of Good, pp. 67-68.

${ }^{61}$ And, of course, it would also seem to be an adequate reason not to make any sacrifices on their behalf.

${ }^{62}$ Murdoch, The Sovereignty of Good, pp. 101-102.

${ }^{63}$ Ibid., p. 71.

This article is protected by copyright. All rights reserved 
64 Ibid. , p. 87.

65 Ibid., p. 87.

66 See Sarah Buss, "The Value of Humanity," The Journal of Philosophy 59, nos. 5/6 (May/June, 2012): 1-39.

${ }^{67}$ I discuss this issue in "Personal Ideals, Rational Agency, and Moral Requirements" (unpublished manuscript). In "Norms of Rationality and the Superficial Unity of the Mind"(unpublished manuscript). I discuss the limits of incoherence and their relation to the special normative force of wittingly violating formal principles of rationality

${ }^{68}$ See Soren Kierkegaard, Fear and Trembling, trans. by Alastair Hannay (New York: Penguin Books, 1985), pp. 66-82.

69 Thomas Nagel, "The Absurd," in Mortal Questions (Cambridge: Cambridge University Press, 1979), 11-23.

${ }^{70}$ In her extremely powerful record of life under Stalin, Nadezhda Mandelstam declares that she would rather react to her tormenters with fear and rage than with the calm of someone who has lost all sense of entitlement. Fear and rage, she suggests, are tied to hope, and to "self-respect, a sense of one's own worth, rights, needs, and desires." (Mandelstam, Hope Against Hope, p. 42) At the same time, the book reveals the horrible corrupting effect of fear, pressing my guiding question far more eloquently than I possibly could. At one point, Mandelstam tells us: "nobody I knew fought -- all they did was to lie low. This was the most that people with conscience could do -- and even that required real courage." But at other places in the book, she is not so sure that this was enough: "[W]e were all so well disciplined that we took part in the killing of our own kind and justified ourselves by reference to "historical necessity.'”(p. 359) "We all took the easy way out by keeping silent in the hope that not we but our neighbors would be killed. It is even difficult to tell which among us were accomplices to murder, and which were just saving their skins in silence."(p.109) See also the observation about her husband in note 47.)

${ }^{71}$ Arendt puts the point by noting that our "conscience" can be perverted, so that in telling us to resist our impulses, it is telling us to be an accomplice to evil. (See Arendt, Eichmann in Jerusalem, p. 150.)

${ }^{72}$ Karl Ove Knausgard, My Struggle, Book 6 (New York: Archipelago Books, 2018), 614.

73 Ibid., p. 630.

This article is protected by copyright. All rights reserved 
${ }^{74}$ The poem is Paul Celan's “The Straightening."

${ }^{75}$ Ibid., p. 826 See also his comment about Germany under the Nazis: "Neither the I of the body nor the we of the state contained any singular you. It was for this reason that millions of Jews could be sent to the gas chambers before the eyes of everyone, without anything happening other than that they looked down, they looked away, for what was there to see?... Nowhere does anyone ask after you, for 'you' does not exist." (p. 846) It is important, however, not to forget the reflections that have led me to Knausgaard. As Victor Klemperer makes clear in his daily record of this period in his country's history, many Germans looked down and away despite being keenly aware of the humanity of the Jews in their midst, and many of them risked small acts of kindness -- uttering words of support, adding a turnip to a shopping basket, sharing a forbidden newspaper, etc. -- when they thought no one would catch them. If, as Klemperer suggests, many instances of "keeping [one's] head down"(p. 4) and "knuckle[ing] under" (p. 152) were "disgraceful," the disgrace was that of "cring[ing] with fear," (p. 31) not enthusiastically endorsing the regime. (Victor Klemperer, I Will Bear Witness: 1933-41 (New York: Random House, 1998), p. 4, p. 152) Adam Smith nicely captures the distinctive moral liabilities of cowardice and indifference to which I am trying to call attention. [W] so frequently find in the world men of great humanity who have little self-command, but who are indolent and irresolute, and easily disheartened, either by difficulty or danger, from the most honourable pursuits; and, on the contrary men of the most perfect selfcommand, whom no difficulty can discourage, no danger appall, and who are at all times ready for the most daring and desperate enterprises, but who, at the same time, seem to be hardened against all sense either of justice or humanity." (Adam Smith, The Theory of Moral Sentiments III (Cambridge: Cambridge University Press, 2002), p. 178 )(Thanks to Sam Fleischacker for alerting me to this passage.) Though Smith does not conclude that a certain measure of incoherence might be necessary to combine a perfect self-command with a keen sense of humanity, it seems to me that his observations support the idea that the two character types he describes could be embodied in the same individual only if this individual was, to some extent, at odds with herself.

76 "How much and how correctly would we think," Kant asks, "if we did not think as it were in community with others to whom we communicate our thoughts and who communicate theirs with us! Thus one can very well say that [an] external power which wrenches away people's freedom publicly to communicate their thoughts also takes from them the freedom to think ... . that single gem remaining to us in the midst of all the burdens of civil life, through which alone we can derive means of overcoming all the evils of our condition." (Immanuel Kant, "What does it Mean to Orient Oneself in Thinking," trans. by Allen Wood, in Religion and Rational Theology (Cambridge: Cambridge University Press, 1996), pp. 1-18.)

${ }^{77}$ Camus, The Plague, pp. 36-37.

This article is protected by copyright. All rights reserved 
78 Ibid., p. 121.

${ }^{79}$ Ibid., p. 35.

80 Ibid., p. 36

81 Ibid., 125.

(1) 125.

82 Ibid., p. 125.

83 For very different fictional exploration of the problem, see High Noon (1952)

Directed by Fred Zinnemann. Screenplay by Carl Foreman (based on the magazine story "The Tin Star" by John W. Cunningham).

${ }^{84}$ I would like to thank Rebecca Harrison for her editorial help with an early version of this paper. I am also grateful for comments (in writing and/or conversation) from Rudiger Bittner, Tom Dougherty, Daniel Drucker, Samuel Fleischacker, Rebecca Harrison, Don Herzog, Juan Pineros, Massimo Renzo, Adam Wagner, and Robin Zheng. Some of these comments came very late in the writing process. I hope to have the opportunity to benefit from them more fully in future work, as I hope to incorporate into this work the insights of the four commentaries I have not yet had the opportunity to read. My greatest debts are to Jonathan Vogel and Elizabeth Brake. After reading an early draft of the paper, Jonathan raised many important concerns. I had known that these issues needed to be addressed. But I might not have revised the paper in the same ways, to the same extent, had he not become one of my imaginary interlocutors. In addition to making helpful suggestions about the text, Elizabeth has been an invaluable guide throughout the drafting process. She, too, has my heartfelt thanks.

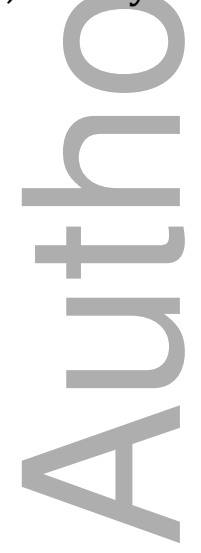

This article is protected by copyright. All rights reserved 